\title{
Thermodynamic Aspects and Reprogramming Cellular Energy Metabolism during the Fibrosis Process
}

\author{
Alexandre Vallée ${ }^{1, *}\left(\mathbb{D}\right.$, Yves Lecarpentier ${ }^{2}$ and Jean-Noël Vallée ${ }^{1,3}$ \\ 1 Laboratory of Mathematics and Applications (LMA), DACTIM, UMR CNRS 7348, \\ CHU de Poitiers and University of Poitiers, 86021 Poitiers, France; valleejn@gmail.com \\ 2 Centre de Recherche Clinique, Grand Hôpital de l'Est Francilien (GHEF), 77100 Meaux, France; \\ yves.c.lecarpentier@gmail.com \\ 3 CHU Amiens Picardie, University of Picardie Jules Verne (UPJV), 80025 Amiens, France \\ * Correspondence: alexandre.g.vallee@gmail.com
}

Received: 4 October 2017; Accepted: 21 November 2017; Published: 27 November 2017

\begin{abstract}
Fibrosis is characterized by fibroblast proliferation and fibroblast differentiation into myofibroblasts, which generate a relaxation-free contraction mechanism associated with excessive collagen synthesis in the extracellular matrix, which promotes irreversible tissue retraction evolving towards fibrosis. From a thermodynamic point of view, the mechanisms leading to fibrosis are irreversible processes that can occur through changing the entropy production rate. The thermodynamic behaviors of metabolic enzymes involved in fibrosis are modified by the dysregulation of both transforming growth factor $\beta$ (TGF- $\beta$ ) signaling and the canonical WNT / $\beta$-catenin pathway, leading to aerobic glycolysis, called the Warburg effect. Molecular signaling pathways leading to fibrosis are considered dissipative structures that exchange energy or matter with their environment far from the thermodynamic equilibrium. The myofibroblastic cells arise from exergonic processes by switching the core metabolism from oxidative phosphorylation to glycolysis, which generates energy and reprograms cellular energy metabolism to induce the process of myofibroblast differentiation. Circadian rhythms are far-from-equilibrium thermodynamic processes. They directly participate in regulating the TGF- $\beta$ and WNT/ $\beta$-catenin pathways involved in energetic dysregulation and enabling fibrosis. The present review focusses on the thermodynamic implications of the reprogramming of cellular energy metabolism, leading to fibroblast differentiation into myofibroblasts through the positive interplay between TGF- $\beta$ and WNT / $\beta$-catenin pathways underlying in fibrosis.
\end{abstract}

Keywords: aerobic glycolysis; canonical WNT/ $\beta$-catenin pathway; circadian rhythms; fibrosis; TGF- $\beta$; Warburg effect

\section{Introduction}

Fibrosis is an irreversible and non-physiological scarring process associated with inflammation and increased extracellular matrix (ECM) deposition contributing to tissue damage. Fibrosis is characterized by fibroblast proliferation, fibroblast differentiation into myofibroblasts, and synthesis of ECM including collagen and proteoglycans. Several causes are known for fibrosis, such as infection, alcohol, drug, genetic alterations, radiation, or environmental factors [1]. Fibrosis is not restricted to some tissues but can occur in all organs and tumors [2-5]. A common pathogenic pattern exists in which fibroblasts are ECM producers [1]. Fibroblast proliferation increases in fibrosis, and myofibroblasts are the differentiated form of fibroblasts [6]. Myofibroblasts can derive from bone-marrow-derived fibrocytes, pericytes, vascular smooth muscle cells, or tissue-resident fibroblasts [7-9].

From a thermodynamic point of view, myofibroblastic cells arise from exergonic processes and generate heat within their surroundings. The mechanisms leading to the development of fibrosis 
are similar to many irreversible processes that can occur due to a change in the entropy production rate [10-13].

Several molecular mechanisms can induce and develop the fibrotic process. In fibrosis, thermodynamic behaviors of metabolic enzymes are modified by the dysregulation of both transforming growth factor $\beta$ (TGF- $\beta$ ) signaling and the canonical WNT/ $\beta$-catenin pathway $[14,15]$.

Upregulation of TGF- $\beta 1$ activates lactate dehydrogenase (LDH) expression, leading to lactate production, and induces fibroblast differentiation into myofibroblast and excessive collagen deposition [16,17]. Myofibroblasts are non-muscle contractile cells containing alpha-smooth muscle actin $(\alpha-\mathrm{SMA})$, and are characterized by a dramatic slowness of their contractile kinetics $[18,19]$.

Upregulation of the canonical WNT/ $\beta$-catenin pathway activates pyruvate dehydrogenase kinase-1 (PDK-1), which decreases pyruvate dehydrogenase complex (PDH) activity. Upregulation of canonical WNT/ $\beta$-catenin pathway also stimulates Lactate Dehydrogenase A (LDH-A) and monocarboxylate lactate transporter-1 (MCT-1) [20]. Thus, WNT/ $\beta$-catenin activation decreases the conversion of pyruvate into acetyl-coenzyme A (acetyl-CoA) in mitochondria and its entry into the tricarboxylic acid (TCA) cycle. At this step, a major part of cytosolic pyruvate is converted into lactate as the primary alternative of oxidative phosphorylation despite the availability of oxygen, a phenomenon called aerobic glycolysis or the Warburg effect [21].

TGF- $\beta 1$ and WNT / $\beta$-catenin pathways leading to fibrosis can be considered dissipative structures that exchange energy or matter with their environment [22]. These pathological processes operate as far-from-equilibrium open systems. Circadian rhythms are also far-from-equilibrium thermodynamic processes [11,12].

We focus this review on the thermodynamic implications in the reprogramming of cellular energy metabolism, enabling fibroblast differentiation into myofibroblasts through the positive interplay of the molecular signaling pathways TGF- $\beta$ and WNT/ $\beta$-catenin underlying the fibrotic process.

\section{Thermodynamic Aspects of Myofibroblasts}

Myofibroblasts are contractile non-muscle cells that exhibit bundles of actin filament containing $\alpha$-SMA. Myofibroblasts are connected by $\alpha$-SMA peripheral focal adhesions and gap junctions in the granulation tissue [23]. Fibroblasts become protomyofibroblasts. Protomyofibroblasts synthetize ECM, collagen, and fibronectin for their differentiation into myofibroblasts [24] containing $\alpha$-SMA and non-muscle myosin II (NMII), responsible for the retractile role of myofibroblasts [25].

Differentiation of fibroblasts into myofibroblasts requires the participation of physical and chemical factors such as an increase in tissue stiffness $[26,27]$ and the activated TGF- $\beta 1$ association with the fibronectin extra domain A (EDA) [24,28]. The activated TGF- $\beta 1$-promoted $\alpha$-SMA increases the contractile property of myofibroblasts [29]. Transmission of the contractile force generated by $\alpha$-SMA and the molecular motor myosin are performed by ECM through focal adhesions containing transmembrane integrin [30]. TGF- $\beta 1$ activation in ECM is an integrin-dependent process [31].

The molecular motor of myofibroblasts is the non-muscle myosin IIA (NMIIA) [32]. NMIIA is characterized by three pairs of chains, including two $230 \mathrm{kDa}$ heavy chains, two $20 \mathrm{kDa}$ regulatory light chains (RLCs) that stimulate the activity of NMII, and two $17 \mathrm{kDa}$ essential light chains (ELCs) that stabilize the structure of heavy chains. NMII is responsible for cell polarity, cell-cell adhesion, and cell migration.

Myosin filaments link actin filaments in thick contractile actomyosin bundles like stress fibers. The NMIIA molecules assemble into bipolar filaments. A tilted state of the myosin head enables a conformational change that moves actin filaments in an anti-parallel manner. The actin-myosin cross-bridge (CB) cycle of NMIIA is overall like smooth and striated muscle myosin. An ATP molecule binds the NMIIA-ATPase site on the head of the myosin, which enables the dissociation of actin from the NMIIA head, and the ATP hydrolysis. Subsequently, NMIIA binds to actin. The power stroke then occurs with a tilt of the NMIIA head, generating a CB single force with a displacement of few 
nanometers, and then releasing ADP from the acto-NMIIA complex, as the final stage of a CB cycle. A new CB cycle starts when a new ATP molecule dissociates actin from the myosin head.

From a thermodynamic point of view, contractile tissues are open biological systems not in equilibrium state through the exchanges of energy and matter with their surroundings, and can operate either close to or far away from thermodynamic equilibrium [10,33]. In the physiological state, muscular and non-muscular contractile tissues, which have the ability to contract and relax, have been shown to be open chemical systems maintained in a near-equilibrium thermodynamic state that operate under a linear regime, evolving to a stationary state in which the entropy production rate is minimal [33].

However, the singularity of the motor molecular NMIIA that characterizes contractile non-muscular myofibroblast cells is its dramatically slow cycle of contractile kinetics compared to that of myosin of contractile muscle cells [18,19]. Indeed, myofibroblasts occur physiologically in organs such as in stem villi of the human placenta during normal pregnancies. In these contractile non-muscle cells of the human placenta, the rate of attachment and detachment of the actin-myosin CB, and the catalytic constant are lower than those of striated or smooth muscles, although, the actin-myosin $\mathrm{CB}$ single force of NMIIA is on the same order of magnitude as muscle myosin II (MII) [33]. This singularity confers a particular thermodynamic profile for NMIIA with low thermodynamic flow, low myosin content and ATPase activity of NMIIA, and low thermodynamic entropy production rate compared with contractile muscle tissues [33]. Such a stationary contractile system ensures that numerous contraction-relaxation cycles operate at a near-equilibrium thermodynamic state, mainly through mitochondrial oxidative phosphorylation energy metabolism.

In the fibrosis process, myofibroblasts generate a relaxation-free contraction mechanism associated with excessive collagen synthesis in the ECM that promotes irreversible tissue retraction, evolving towards fibrosis and finally apoptosis of myofibroblasts [33-36].

The mechanisms leading to fibrosis are like many irreversible processes that can occur due to a change in the entropy production rate. This rate represents a thermodynamic quantity, such as heat production, Gibbs energy, or ionic conductance, and quantifies these irreversible processes [10-13]. The myofibroblast cells arise from exergonic processes, mainly through glycolysis energy metabolism and generate heat within the surrounding environment.

The molecular signaling pathways leading to the development of fibrosis are considered as dissipative structures that exchange energy or matter with their environment. They operate as far-from-equilibrium open thermodynamic systems under non-linear regime evolving to non-stationary states. Circadian rhythms are also dissipative structures that operate as far-from-equilibrium thermodynamics $[11,12]$. Moreover, circadian rhythms directly participate in regulating the molecular pathway TGF- $\beta$ [37] and WNT/ $\beta$-catenin [38] is involved in the reprogramming of cellular energy metabolism, enabling fibroblast differentiation into myofibroblasts.

\section{TGF- $\beta 1$, Reactive Oxygen Species, and the Fibrotic Process}

The production [39-41] and activity [17] of TGF- $\beta 1$ are stimulated in fibrosis. TGF- $\beta 1$ activation induce the transformation of fibroblasts into $\alpha$-SMA-expressing myofibroblasts, and the excessive synthesis of ECM proteins including collagen and metalloproteinases (MMPs) [42-46]. TGF- $\beta 1$ and Smad pathways interact in myofibroblasts through the phosphorylation of Smad2 and Smad3 by TGF- $\beta$ receptor 1 (TGF- $\beta R 1$ ). TGF- $\beta 1$ binds TGF- $\beta R 2$ and their interaction with TGF- $\beta R 1$ forms a heterotetramer for the Smad 2 and Smad 3 phosphorylation. Then, Smad2/3 binds Smad4, and the complex thus formed translocates to the nucleus for activation of the Smad binding element (SBE) [47]. TGF- $\beta 1$ activation also stimulates Smad-independent pathways, such as the phosphatidylinositol 3-kinase/serine/threonine kinase (protein kinase B) (PI3K/Akt) pathway [48]. PI3K/Akt pathway activation is involved in collagen synthesis via TGF- $\beta 1$ signaling [49-51] (Figure 1). 


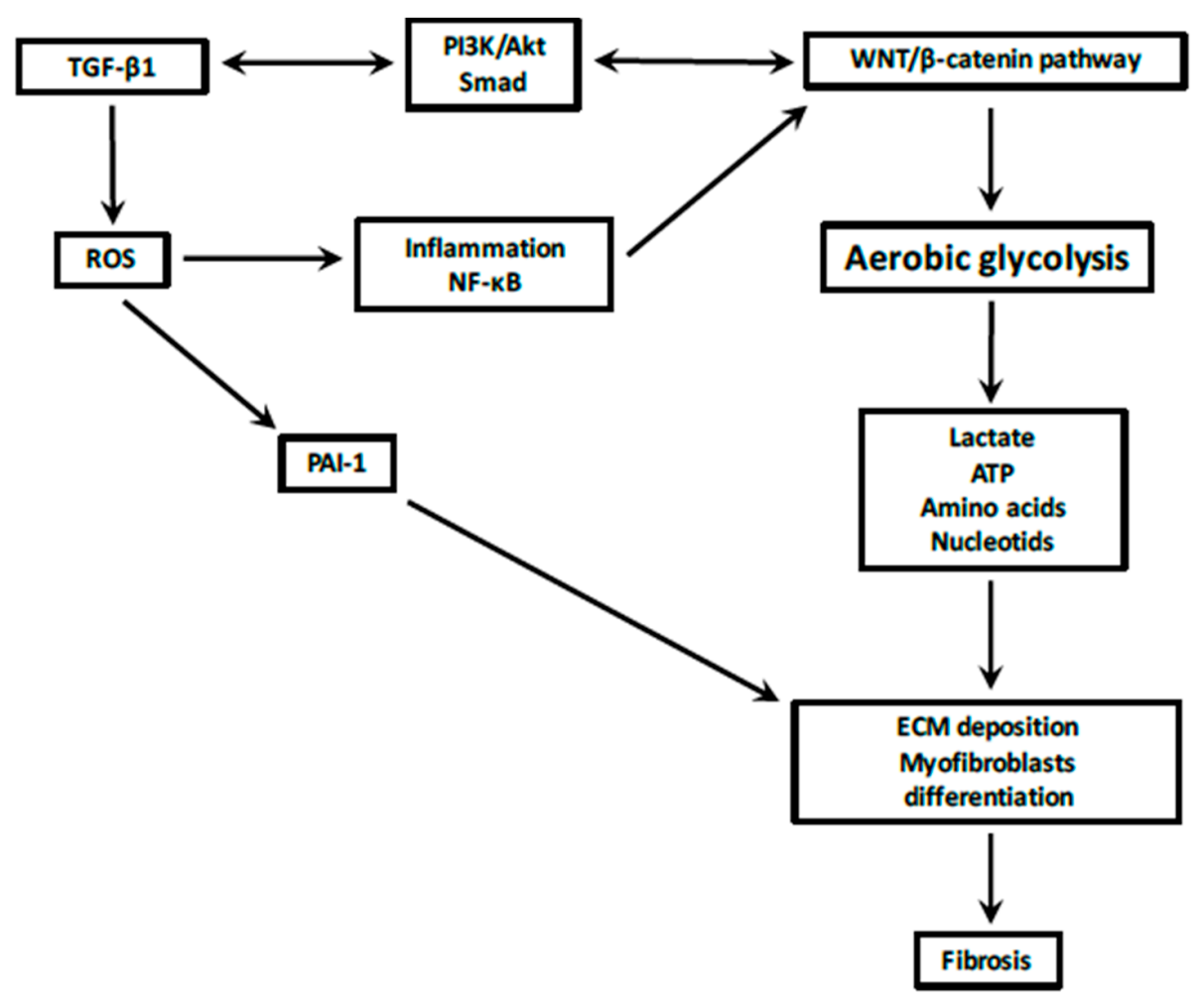

Figure 1. Reprogramming energetic metabolism through the interactions between TGF- $\beta 1$, Transforming growth factor 1 and $\mathrm{WNT} / \beta$-catenin pathway during the fibrotic process. PAI-1, Plasminogen Activator Inhibitor 1; NF-кB, NFkappaB; ROS, Reactive Oxygen Species; PI3K, Phosphatidylinositol-4,5-biphosphatase 3-kinase.

Several studies have shown that reactive oxygen species (ROS) have a major role in the fibrosis process. ROS production has been observed in several fibrotic tissues such as renal fibrosis and fibrotic myocardial infarction [52-56]. ROS production leads to the activation of cytokines and growth factors [57-59], and the production of various enzymes, such as NADPH oxidase (named NOX) [60]. The NOX enzyme has a main role in the fibrotic process [61,62]. NOX-derived ROS is associated with fibrotic pathway in several organs, such as lung [63], heart [64], kidney [65], pancreas [66], and liver [67-69]. ROS and TGF- $\beta 1$ are linked and considered major keys to fibrosis $[58,70]$.

ROS production is enhanced by TGF- $\beta 1$ activation [1], and TGF- $\beta 1$-mediated NOX4 expression promotes ROS production [64,71-73]. NOX expression is upregulated in several models of fibrosis [74]. TGF- $\beta 1$ stimulates ROS generation by inducing NOX expression [75]. Inhibition of NOX4 induces downregulation of TGF- $\beta 1$ expression and then diminution of ECM deposition $[63,76]$. During the fibrotic process, TGF- $\beta 1$ activated binds Smad2/3 or PI3K signaling and then activates NOX4 expression. NOX4 in turn stimulates ROS production, which activates the proliferation, migration, and differentiation of fibroblasts and induces ECM deposition [1]. TGF- $\beta 1$, by activating epidermal growth factor receptor (EGFR) signaling, stimulates the expression of the potent profibrotic matricellular plasminogen activator inhibitor-1 (PAI-1), which encodes the structural elements of ECM such as fibronectin and collagen 1 [77-80]. PAI-1 is one of the most important precursors in tissue inflammation and fibrosis [81], limiting the degradation of ECM and facilitating the accumulation of matrix structural elements [82,83]. TGF- $\beta 1$-induced PAI-1 expression is involved in ROS signaling, leading to the regulation of strong interactions with Smad and non-Smad axes [84], and then enhances EGFR cascade [85] and TGF- $\beta 1$ R1-directed Smad2/3 phosphorylation [86]. ROS generation activates c-Src and subsequently the phosphorylation of EGFR, which stimulates the MEK-ERK1/2 cascade, which is an activator of p53 [87] (Figure 2). 


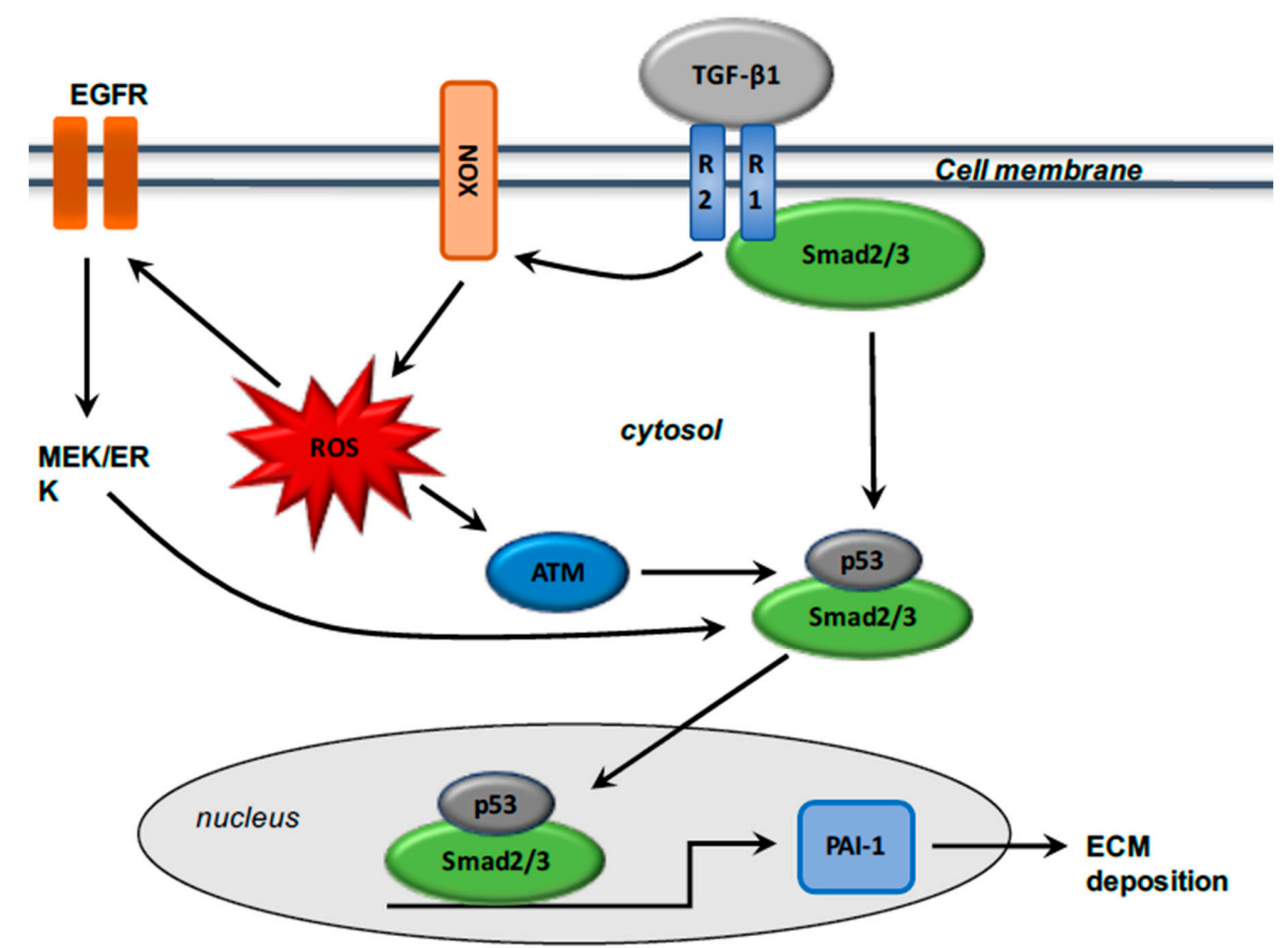

Figure 2. Interactions between Smad and non-Smad pathways with TGF- $\beta 1$ signaling. TGF- $\beta 1$ receptor (TGF- $\beta$ R1) activation, consequent to the ligand TGF- $\beta 1$ engagement, initiates the activation of Smad2/3 (through the phosphorylation of Smad2 and Smad3 by TGF- $\beta$ R1), non-Smad (EGFR) mediated downstream pathways (like PAI-1,) and phenotypic modifications (like myofibroblast differentiation and extracellular matrix deposition/fibrosis). TGF- $\beta 1$, by inducing NOX expression, activates ROS generation, which enhances the initiation of non-Smad (EGFR) and the modulation of Smad (maintenance of Smad phosphorylation). The p53 transcription factor integrates transcriptional contributions from both Smad and non-Smad cascades. ROS generation by TGF- $\beta 1$ stimulation is crucial for p53 activation (by phosphorylation and acetylation).

Several studies have shown that tumor suppressor p53 is a critical factor in the fibrotic process [88]. Moreover, ROS generation is considered an upstream influence on p53 signaling through the stimulation of ataxia telangiectasia mutated (ATM) [89] in injured tissues [90] and in mouse embryo fibroblasts [91]. TGF- $\beta 1$ stimulates p53 by phosphorylation and then leads to the activated phosphorylated Smad2/3/p53 complex [88], which binds to PAI-1 [92]. Interactions between p53 and the Smad pathway are crucial for activation of PAI-1 via TGF- $\beta 1$, suggesting crosstalk between Smad and non-Smad such as p53 and NOX [93].

ROS production and inflammation act in a vicious circle in which inflammation stimulates ROS, which in turn enhance inflammation through activation of the NF- $\kappa B$ pathway [94-96]. In parallel, ROS production causes DNA damage in endothelial cells and induces activation of the canonical WNT/ $\beta$-catenin pathway [97].

\section{Canonical WNT/ $\beta$-Catenin Pathway during the Fibrotic Process}

The canonical WNT/ $\beta$-catenin pathway is upregulated in fibrotic tissues such as the liver, skin, lungs, kidneys, and heart [98-103]. Wingless and the integration site (named WNT) pathway consist of a cascade of numerous signaling involved in cell development, cell metabolism, cell growth, and stem cell maintenance [104]. The WNT pathway is formed by secreted lipid-modified glycoproteins [105]. Dysregulation of the canonical WNT pathway is observed in several tumor and non-tumor diseases [106]. 
WNT extracellular ligands bind Frizzled (FZD) receptors, low-density lipoprotein receptor-related proteins 5 and 6 (LRP 5/6), and disheveled (DSH), which results in $\beta$-catenin accumulation and then nuclear $\beta$-catenin translocation to bind with the T-cell factor/lymphoid enhancer factor (TCF/LEF) [107]. TCF/LEF, related to nuclear $\beta$-catenin, activates the transcription of WNT target genes such as c-Myc and cyclin D1 [108].

Downregulation of the WNT/ $\beta$-catenin pathway leads to the absence of binding between the extracellular WNT ligands and the FZD/LRP $5 / 6$ complex. Thus, adenomatous polyposis coli (APC), AXIN and glycogen synthase kinase- $3 \beta$ (GSK-3 $\beta$ ) form a $\beta$-catenin destruction complex and mediate the proteasomal $\beta$-catenin degradation [109]. GSK-3 $\beta$ inhibits the accumulation of $\beta$-catenin and its nuclear translocation $[109,110]$.

\subsection{Inflammation and the WNT/ $\beta$-Catenin Pathway}

NF- $\mathrm{BB}$ signaling, a key mediator of inflammation [94,111,112], is upregulated in numerous inflammatory pathways $[94,112,113]$. The positive interplay between NF-KB signaling and the canonical WNT/ $\beta$-catenin pathway regulates the immune response and inflammation [114-117]. The activation of NF-KB increases the expression of the TCF/LEF complex and exerts an indirect positive influence on the $\mathrm{WNT} / \beta$-catenin pathway [118]. The activation of $\mathrm{WNT} / \beta$-catenin pathway increases NF-KB-mediated anti-apoptotic action $[119,120]$, and stimulates inflammatory processes by stimulating $\beta$-catenin to target genes [121,122]. The activation of $\beta$-catenin/TCF4 increases the NF- $\mathrm{KB}$ activity in vascular smooth muscle cells [123]. Inflammation increases the production of collagen and the release of inflammatory chemokines in the development of liver fibrosis [124]. In fibrosis, CCN4, a WNT-inducible signaling pathway protein-1 (WISP1), is stimulated and leads to fibroblast proliferation and ECM synthesis $[125,126]$. The activation of CCN4 induces morphological transformation in skin fibrosis [127]. In hepatic fibrosis, $\mathrm{CCl} 4 \mathrm{mAb}$, a specific inhibitor of CCN4, decreases NF- $\mathrm{kB}$ activity and then downregulates the expression of pro-fibrotic factors such as TGF- $\beta 1$ [128].

\subsection{The WNT/B-Catenin and PI3K/Akt Pathways}

The phosphatidylinositol 3-kinase/serine/threonine kinase (protein kinase B)/mammalian target of rapamycin (PI3K/Akt/mTOR) pathway is involved in cell growth, cell proliferation, protein synthesis, and energetic metabolism [129-132]. WNT/ $\beta$-catenin pathway is an upstream activator of the PI3K/Akt/mTOR pathway [133] by inhibiting GSK-3 $\beta$ activity [134]. GSK-3 $\beta$, a crucial inhibitor of the WNT/ $\beta$-catenin pathway [135]), is a specific intracellular serin-threonin kinase involved in the regulation of numerous pathophysiological processes, such as cell membrane signaling and inflammation [136-138]. Moreover, in adipocyte differentiation, the activated PI3K/Akt pathway inhibits GSK-3 $\beta[139,140]$. Inhibition of the PI3K/Akt pathway suppresses collagen synthesis in human and rat hepatic stellate cells $[141,142]$ and protects against pulmonary and kidney fibrosis $[143,144]$. In addition, downregulation of $\beta$-catenin signaling decreases the expression of the PI3K/Akt/mTOR pathway $[145,146]$. The WNT/ $\beta$-catenin and PI3K/Akt/mTOR pathways stimulate each other, increasing NF- $\mathrm{kB}$ signaling. The activation of GSK3- $\beta$ also decreases NF- $\kappa B$ signaling $[147,148]$.

\section{Interactions between the TGF- $\beta 1$ and Canonical WNT/ $\beta$-Catenin Pathways}

WNT3a, a canonical WNT ligand, activates TGF- $\beta 1$ expression via $\beta$-catenin-dependent Smad2 activation, leading to the differentiation of fibroblasts into myofibroblasts [149]. Conversely, the absence of WNT ligands leads to the attenuation of TGF- $\beta$ expression and fibrotic response [150]. GSK-3 $\beta$ activation phosphorylates Smad proteins and leads to their degradation [151].

Moreover, activation of TGF- $\beta$ also stimulates the WNT pathway by inhibiting dickkopf-related protein 1 (DKK1) expression, an inhibitor of WNT/ $\beta$-catenin pathway [152]. After TGF- $\beta$ and WNT stimulation, AXIN facilitates the Smad2/3 binding with a TGF- $\beta$ type 1 receptor and then Smad2/3 activation [153] (Figure 3). 


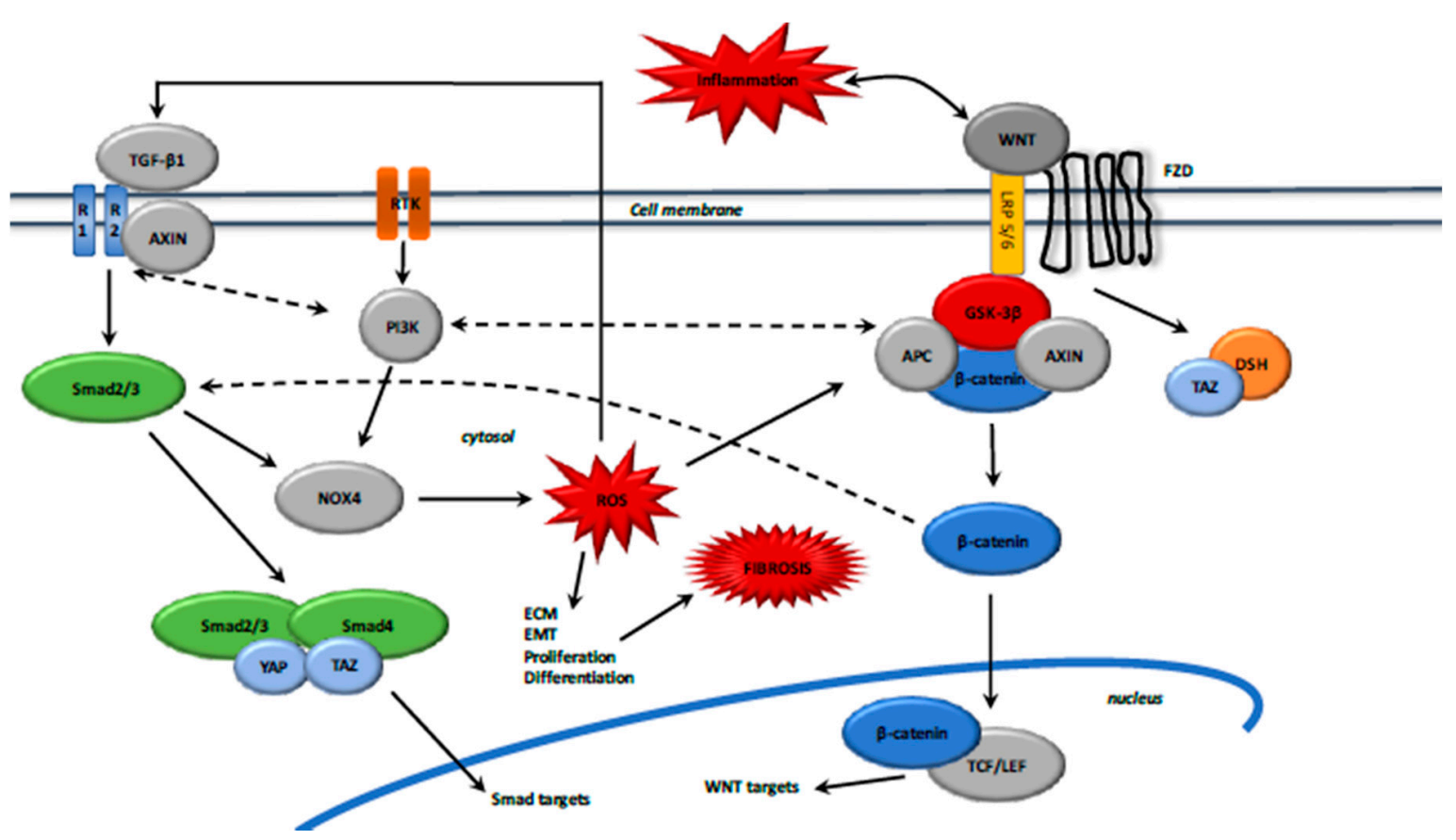

Figure 3. Interactions between TGF- $\beta 1$ and canonical WNT/ $\beta$-catenin pathway in fibrosis. Anflamation activates TGF- $\beta 1$ and the WNT/ $\beta$-catenin pathway. WNT activation inhibits the $\beta$-catenin destruction complex, which results in the $\beta$-catenin accumulation in the cytosol and then its translocation to the nucleus for activating WNT target genes. Upon WNT stimulation, TAZ inhibits the phosphorylation of DSH and dissociates it from the $\beta$-catenin destruction complex. The destruction complex is inhibited because YAP and TAZ dissociate from the complex. Upon TGF- $\beta$ stimulation, AXIN promotes the tail-phosphorylation of Smad2/3. The activated Smad2/3-Smad4 complex associates with TAZ and YAP and then translocates to the nucleus for activating Smad targets. TGF- $\beta 1$ induces Smad $2 / 3$ and PI3K/Akt pathway activation, which in turn stimulates NOX4 activity. NOX4 enhances ROS to activate ECM, EMT, proliferation and differentation. ROS accumulation also enhances the TGF- $\beta 1$ release and activation of the TGF- $\beta 1$ in a positive feedback loop. TGF- $\beta 1$, Transforming Growth Factor 1; PI3K, Phosphatidylinositol-4,5-biphosphatase 3-kinase; ROS, Reactive Oxygen Species; YAP, Yes-associated protein; TAZ, Transcriptional coactivator with PDZ-binding motif; DSH, Disheveled.

Upon WNT ligand activation, AXIN forms a complex with Smad7 and the E3 ubiquitin ligase Arkadia to promote the degradation of Smad7 [154], which is an inhibitor of the Smad pathway [155]. Activated Smad7 binds YAP (yes-associated protein 1) and Smurf2, which increases the affinity for TGF- $\beta$ type 1 receptor and then decreases TGF- $\beta$ signaling [156]. Activated Smad7 also recruits Smurf2 to induce ubiquitination and proteasomal $\beta$-catenin degradation [157].

YAP and TAZ (a transcriptional coactivator with PDZ-binding motif) mechanical signaling drives persistent fibroblast activation and sustainable fibrogenesis. Elevated YAP and TAZ levels are observed in fibrosis [158]. YAP and TAZ knockdown in cultured lung and liver fibroblasts reduces the levels of protein associated with myofibroblast differentiation, such as pro-collagen and $\alpha$-SMA [159]. During fibrosis, F-actin polymerization inactivates the Hippo core kinase complex, leading to YAP and TAZ dephosphorylation and their translocation to the nucleus [15].

Stimulation by WNT3a inhibits the destruction complex because YAP/TAZ dissociates from the $\beta$-catenin destruction complex and then allows $\beta$-catenin nuclear translocation. TAZ binds DSH and dephosphorylates it upon stimulation with WNT3a. Then TAZ dissociates DSH from the destruction complex [160]. Indeed, in the absence of WNT ligands, phosphorylated YAP and TAZ bind $\beta$-catenin with activated GSK-3 $\beta$ and AXIN to degrade $\beta$-catenin in the proteasome [161]. In fibrosis, the activated Smad2/3-Smad4 complex is associated with YAP and TAZ for its translocation to the nucleus [162]. 
Crosstalk of several components of the TGF- $\beta, \mathrm{WNT}$, and YAP/TAZ signaling plays a key role in the tuning of nucleocytoplasmic shuttling of fibrosis [15].

TAZ is also a downstream mediator of WNT signaling, independent of Hippo signaling [163]. The activation of WNT/ $\beta$-catenin inhibits the phosphorylation of $\beta$-catenin and releases it from the destruction complex, which prevents TAZ degradation, resulting in the concomitant $\beta$-catenin and TAZ accumulation.

WNT/ $\beta$-catenin signaling induces $\beta$-catenin and TAZ accumulation and activation of the TAZ-dependent gene responses [163].

The non-Smad pathways such as MAPK, TGF- $\beta$ activated kinase (TAK1), JNK, or PI3K/ Akt are also involved in interactions between TGF- $\beta 1$ and canonical WNT/ $\beta$-catenin pathways $[164,165]$. Phosphatase and tensin homolog (PTEN), a PI3K/Akt pathway inhibitor [166], inhibits the differentiation of fibroblast into myofibroblasts, as well as collagen and $\alpha$-SMA expression [167].

\section{Aerobic Glycolysis and the Fibrotic Process}

The Warburg effect is involved in various tumor and non-tumor diseases [168] and occurs during the process of fibroblast differentiation into myofibroblasts [169]. The Warburg effect is described as a shift in energy production from mitochondrial oxidative phosphorylation to aerobic glycolysis despite the availability of oxygen [21].

Although aerobic glycolysis produces fewer ATP molecules than mitochondrial oxidative phosphorylation, glycolysis is much faster than oxidative phosphorylation [170]. Consequently, aerobic glycolysis may produce more total ATP than mitochondrial oxidative phosphorylation in the same amount of time [171].

Aerobic glycolysis generates the energy and metabolites involved in the regulation of cellular functions, including proliferation, extracellular matrix production, autophagy, and apoptosis [172].

In fibrosis, aerobic glycolysis provides the necessary ATP, amino acids, and nucleotides for ECM synthesis [173], and is actively involved in reprogramming cellular metabolism to enable fibroblast differentiation into myofibroblasts. Fibroblast cells support their differentiation by reprogramming nutrient uptake and metabolism. The main nutrients that myofibroblast cells use are glucose and the amino acid glutamine, which are essential to many metabolic processes involved in fibrosis.

From an energy metabolism perspective, the TGF- $\beta 1$ and $W N T / \beta$-catenin pathways are central regulators of glycolytic energy metabolism in fibrosis.

Glycolysis is induced in a hypoxia-independent manner by (1) the WNT/ $\beta$-catenin pathway activation via direct activation of WNT target genes, PDK1 and MCT-1, and via the stabilization of hypoxia-inducible factor 1 alpha (HIF-1 $\alpha$ ) [168,174-176]; and (2) TGF- $\beta 1$ pathway activation via HIF-1 $\alpha$ stabilization [16].

The TGF- $\beta 1$ and WNT/ $\beta$-catenin pathways activate each other in a positive feedback loop through (1) Smad signaling pathway via Smad2/3, Smad2/3/NOX4/ROS, and the Smad2/3-4 complex/YAP/TAZ, dependent on Hippo signaling; and (2) non-Smad signaling pathways such as MAPK, TAK1, JNK, and PI3K/Akt signaling (Figure 4).

HIF- $1 \alpha$ stabilization is sustained in a hypoxia-independent manner through the molecular signaling pathways, which consist of (1) WNT/ $\beta$-catenin target genes, c-Myc and cyclin D1; (2) WNT/ $\beta$-catenin-induced PI3K/Akt; (3) TGF- $\beta 1$-induced PI3K/Akt; (4) WNT/ $\beta$-catenin-induced TAZ independent of the Hippo signaling; PKM2/ $\beta$-catenin complex-induced c-Myc; and (5) the positive interplay between the TGF- $\beta 1$ and $\mathrm{WNT} / \beta$-catenin pathways. 


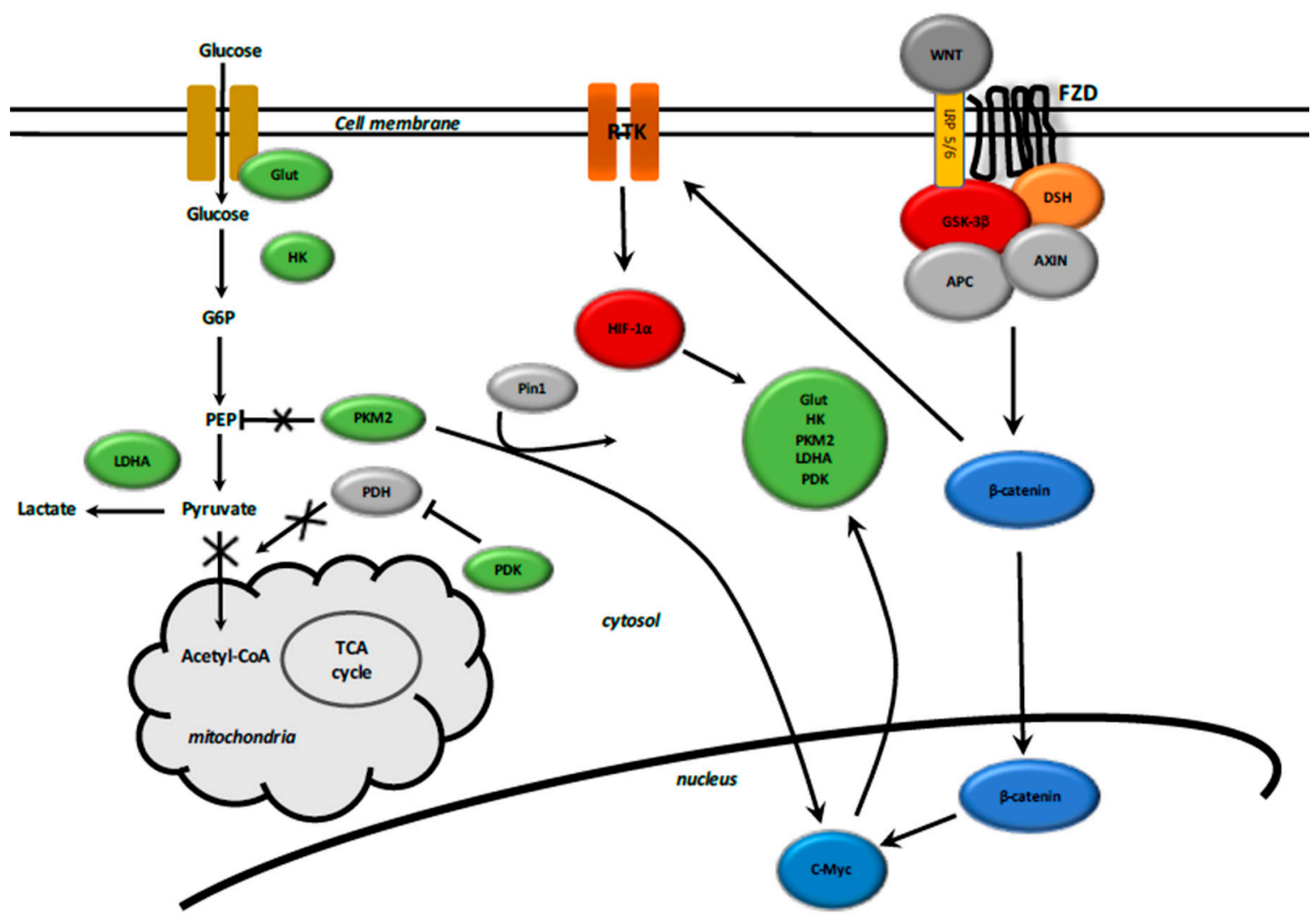

Figure 4. Interactions between $\mathrm{WNT} / \beta$-catenin pathway and aerobic glycolysis. WNT ligands bind both Frizzled and LRP 5/6 receptors to initiate LRP phosphorylation of the AXIN/APC/GSK-3 $\beta$ complex. $\beta$-catenin phosphorylation is inhibited and this prevents its degradation in the proteasome. $\beta$-catenin accumulates into the cytosol and then translocates to the nucleus to bind TCF-LEF co transcription factors. WNT-response gene transcription is stimulated (PDK, c-Myc, cyclin D, MCT-1). MCT-1 promotes the release of lactate out of the cell. WNT/ $\beta$-catenin pathway activates tyrosine kinase receptors (TKRs). Activation of PI3K/Akt increases glucose metabolism. Akt-transformed cells induce HIF-1 $\alpha$ stabilization, which largely diminishes the glucose entry into the TCA cycle. Stimulate HIF- $1 \alpha$ activity increases expression of glycolytic enzymes (GLUT, HK, PKM2, LDH-A). Elevated aerobic glycolysis is observed with increased production of lactate and decreased mitochondrial respiration. HIF-1 $\alpha$ induced PDK phosphorylates PDH, which results in cytosolic pyruvate being shunted into lactate through induction of LDH-A. PDK inhibits the PDH complex into mitochondria. Thus, pyruvate cannot be fully converted into acetyl-CoA and enter the TCA cycle. c-Myc and cyclin D also activate LDH-A which converts cytosolic pyruvate into lactate. Activated PKM2 translocates to the nucleus through Pin1, then binds $\beta$-catenin and induces c-Myc expression. This activates GLUT, PKM2 and LDH-A in a positive feedback.

HIF- $1 \alpha$ is a heterodimeric nuclear transcription factor composed of two subunits: HIF-1alpha and HIF-1 $\beta$. HIF- $1 \alpha$ stabilization results in its nuclear translocation, dimerization with HIF- $1 \beta$, and the transcription of genes encoding glycolysis enzymes [177]. HIF-1 $\alpha$ undergoes proteasomal degradation after hydroxylation by HIF prolyl-hydroxylases.

Aberrant HIF signaling after HIF- $1 \alpha$ stabilization induces energy metabolism reprogramming in the context of fibrosis by increasing glycolysis energy metabolism and decreasing the entry of glucose-derived carbons into the TCA cycle, reducing the mitochondrial oxidative phosphorylation energy metabolism [178,179]. HIF-1 $\alpha$ represents a central regulator of glycolysis energy metabolism involved in organ fibrosis and a key player in the pathogenesis of lung fibrosis [180]. 
HIFs reprograms glucose and glutamine metabolism to promote the Warburg effect. HIF- $1 \alpha$ stabilization increases glycolysis by (1) overexpression of glucose transporters (Glut) mediating increased glucose uptake and (2) activation of glycolytic enzymes such as Glut, HK2, PKM2, LDH-A, and PDK1 [180-183]. HIF activation promotes lactate production through increasing LDHA expression and decreasing the conversion of pyruvate into acetyl-CoA by upregulating PDK1, resulting in decreased activity of PDH [184,185].

PI3K/Akt signaling is activated by cytosolic $\beta$-catenin accumulation $[145,146]$. Activation of the PI3K/Akt pathway induces HIF-1 $\alpha$ stabilization [183] and is associated with an increased rate of glucose metabolism [186].

Glut-1 and Glut-3 are essential for the insulin-sensitive homeostasis of glucose transport [187]. After glucose enters the cell, the final step of glycolysis is the conversion of the phosphoenolpyruvate (PEP) and ADP into pyruvate and ATP, a reaction catalyzed by the enzyme pyruvate kinase (PK). PK has four isoforms: PKM1, PKM2, PKL, and PKR. The PKM2 dimeric form has low affinity with PEP [188]. Under high glucose concentration, PKM2 is acetylated and translocated to the nucleus through the action of the peptidyl-prolyl isomerase 1 (Pin1) [189], which reduces its activity and targets PKM2 towards a lysosome-dependent degradation [190]. Nuclear PKM2 binds nuclear $\beta$-catenin and then induces c-Myc-mediated expression of glycolytic enzymes including Glut, LDH-A, PDK1, and PKM2 in a positive feedback loop, thus strengthening aerobic glycolysis [191]. Phosphorylated PKM2 levels are upregulated in fibrotic kidneys [192].

The allosteric enzyme phosphofructokinase (PFK) catalyzes the conversion from $\beta$-D-fructose6-phosphate to $\beta$-D-fructose-1,6-biphosphate and stimulates aerobic glycolysis during fibroblast differentiation into myofibroblasts to generate sufficient energy and stabilize HIF- $1 \alpha$ levels [180]. This conversion uses ATP and is responsible for glycolytic oscillations, leading to instabilities from which a novel state can be organized in time and space, driven by PFK with a positive feedback accountable for periodic behavior [193]. In addition, PFK has been shown to be a dissipative structure responsible for energetic metabolism behaving far from equilibrium [36,194].

The shunting of glucose carbons far from the TCA cycle results in glutamine metabolism reprogramming. The WNT target gene c-Myc stimulates glutaminolysis and drives glutamine uptake into the cytosol and the mitochondria [195]. c-Myc-activated HIF shifts from oxidative decarboxylation to reductive carboxylation of glutamine to generate citrate and acetyl-CoA for lipid synthesis [196-198]. c-Myc-induced glutamine enhances aspartate and nucleotide synthesis [195] by HIF- $1 \alpha$ stabilization, which activates PDK1 [199]. Then, a minor part of the pyruvate is converted into acetyl-CoA, which enters the TCA cycle and become citrate for promoting protein and lipid synthesis.

Upregulation of glycolysis, despite an overall decrease in mitochondrial respiration, results in increased levels of the TCA cycle intermediate succinate [200]. The dicarboxylic acid transporter transfers the succinate from the mitochondria to the cytosol. Cytosolic accumulation of succinate inhibits HIF prolyl hydroxylase activity, leading to HIF-1 $\alpha$ stabilization and activation [200]. Buildup of succinate mainly derives from glutamine-dependent anaplerosis via $\alpha$-Ketoglutaric acid $(\alpha \mathrm{KG})$ and the "GABA-shunt" pathway [200]. Moreover, the lowered $\alpha \mathrm{KG} /$ succinate ratio results in lowered HIF prolyl-hydroxylase activity, which uses $\alpha \mathrm{KG}$ as a co-substrate for its enzyme activity and leads to HIF-1 $\alpha$ stabilization $[184,201,202]$. The TCA cycle intermediate succinate is upregulated in lung myofibroblasts. Augmented glycolysis leads to increased succinate, which markedly enhances TGF- $\beta 1$-induced HIF- $1 \alpha$ expression independent of hypoxic conditions, and promotes TGF- $\beta 1$-induced lung fibroblast differentiation into myofibroblasts by binding HIF- $1 \alpha$ to the HIF- $1 \alpha$ responsive element site within the $\alpha$-SMA promoter [200].

TGF- $\beta$ also induces HIF- $1 \alpha$ stabilization and LDH5 expression via TGF- $\beta$-induced HIF- $1 \alpha$ overexpression, which promotes glycolysis energy metabolism and lactate production through activating HIF- $1 \alpha$-regulated glycolytic enzymes in idiopathic pulmonary fibrosis [16]. TGF- $\beta$ is abundantly present in an inactive form that requires cleavage to become biologically active [203-205]. TGF- $\beta$ is known to be activated by heat, enzymatic cleavage, extremes of $\mathrm{pH}$, integrins, and mechanical 
stretching $[203,206,207]$. TGF- $\beta$ is a key cytokine responsible for fibroblast differentiation into myofibroblasts via HIF- $1 \alpha$ overexpression. The transformation of fibroblasts into myofibroblasts that generate excess collagen and other extracellular matrix proteins ultimately leads to scar formation in idiopathic pulmonary fibrosis [208-210]. Moreover, the TGF- $\beta$-induced excessive production of lactic acid resulting from aerobic glycolysis in fibroblasts induces a significant decrease in the $\mathrm{pH}$ with acidification of the metabolic milieu, which in turn promotes activation of latent TGF- $\beta$ to the fibroblast differentiation into myofibroblasts. Thus, this feed-forward loop involved in lactic acid, TGF- $\beta$, HIF- $1 \alpha$, and LDH strengthens aerobic glycolysis and TGF- $\beta$-induced fibroblast differentiation into myofibroblasts in idiopathic pulmonary fibrosis [16]. Stabilization of HIF-1 $\alpha$ promotes TGF- $\beta 1$-induced fibroblast differentiation into myofibroblasts in independent hypoxia signaling [169].

Hypoxia can also be critically involved in fibrosis, and stabilizes HIF- $1 \alpha$ by inhibiting HIF prolyl-hydroxylase, which depends on oxygen as a cofactor for its enzyme activity. Thus, hypoxia causes lowered HIF prolyl-hydroxylase activity, leading to HIF-1 $\alpha$ stabilization [178]. Thus, the fibrotic dissipative process, by switching its core metabolism from oxidative phosphorylation to glycolysis, is responsible for an energetic metabolism behaving far from the thermodynamic equilibrium [36,194].

\section{Circadian Rhythms and Circadian Clock Genes}

Numerous biological systems exhibit oscillatory behaviors such as glycolysis [211,212], or circadian rhythms [211-213] driven by the circadian "clock" (circadian locomotors output cycles kaput). The circadian clock, located in the hypothalamic suprachiasmatic nucleus, displays endogenous and trainable circadian rhythms of free-running periods lasting approximately $24 \mathrm{~h}$.

The numerous transcription factors, responsible for the regulation of circadian rhythms, are circadian locomotor output cycles kaput (Clock), brain and muscle aryl-hydrocarbon receptor nuclear translocator-like 1 (Bmal1), Period 1 (Per1), Period 2 (Per2), Period 3 (Per3), and Cryptochrome (Cry 1 and Cry 2) [214,215]. They are subject to positive and negative self-regulation mediated by circadian rhythms $[216,217]$. The heterodimerization of Clock and Bmal1 enables the transcription of Per1, Per2, Cry1, and Cry2 [218]. The Per/Cry heterodimer, by translocating back to the nucleus, directly represses the Clock/Bmal1 complex and inhibits its own transcription, and thus can inhibit its activation through a negative feedback loop [218].

The Clock/Bmal1 heterodimer also activates the transcription of retinoic acid-related orphan nuclear receptors, Rev-Erbs, and retinoid-related orphan receptors (RORs). Bmal1 transcription can be activated by RORs via a positive feedback loop, whereas they can be repressed by Rev-Erbs via a negative feedback loop [218].

The imbalance of circadian rhythms is directly related to a negative feedback loop performed by a protein on its own gene expression $[219,220]$. Circadian rhythms are dissipative open biological systems that operate, such as to drive the fibrotic process, and work far from the thermodynamic equilibrium by exchanging spontaneously energy and matter with their surroundings, and by changing their cellular entropy production rate [11,221].

Circadian rhythms regulate numerous physiological and metabolic functions, such as heart rate, blood pressure, body temperature, sleep-awake, and feeding patterns [222]. Similarly, circadian rhythms govern energetic metabolism. Oscillation, a cellular process regulating the timing of different biological cycles leading to fibrosis, is driven by multiple irreversible cycles that hydrolyze fuel molecules such as ATP. In such biological systems, a critical amount of energy is needed to drive them to oscillate. A certain amount of energy is consumed per period to reduce the phase diffusion constant and contributes to enhancing the coherence time and phase accuracy of the oscillations. The free-energy dissipation per period, on which the phase diffusion constant depends, is proportional to the number of phase coherent periods [211]. 


\section{Circadian Rhythms and Fibrosis}

The fibrotic process is associated with irregular circadian phases [223-225]. Per2 plays a critical role in fibrosis [226,227]. mPer $2^{-/-}$mouse models develop severe liver fibrosis [226]. Per2 expression plays a protective role in hepatic fibrosis [227]. Diminution of the expression of Per2 exacerbates liver fibrosis and vascular senescence $[227,228]$. Bmal1-deficient fibroblasts show a dysregulation of ROS homeostasis [229]. ROS have their own circadian rhythms [230]. However, the clock-deficiency in mouse models shows low blood pressure [231], which participates in the prevention of renal fibrosis [232]. High blood pressure induces fibrosis, whereas reduction of the blood pressure prevents the fibrotic process $[233,234]$.

ROR expression is increased during fibroblast differentiation into myofibroblasts [235]. ROR activation interacts with the WNT/ $\beta$-catenin and PI3K/Akt pathways to induce mesenchymal transition [236].

\subsection{Circadian Rhythms and TGF- $\beta 1$ Signaling}

Bmal1 has direct transcriptional control on components of TGF- $\beta$ signaling [237]. Smad7 and Smurf2 contain putative Bmal1/Clock-binding sites [238]. Bmal1 stimulation activates TGF- $\beta 1$ by activating Smad 3 and inhibiting GSK-3 $\beta$, and then activates fibroblast differentiation into myofibroblasts [37]. Bmal1 knockout cells show low levels of TGF- $\beta 1$ and Smad proteins [238]. However, GSK-3 $\beta$ activation can decrease the expression of Bmal1 [239]. GSK-3 $\beta$ activation also decreases Smad3 and then downregulates Smad pathway and its target genes [240].

Melatonin (also named 5-methoxy- $N$-acetyltryptamine), naturally secreted by the pineal gland [241], is released during darkness, and thereby regulates sleep [242,243]. Melatonin has anti-inflammatory, antioxidant, and neuroprotective effects [242,244-248]. Melatonin decreases phosphorylation of GSK-3 $\beta[249,250]$ and can prevent pulmonary fibrosis $[251,252]$ by inhibiting pro-fibrotic fibroblasts [253-257] and blocking Bmal1 expression via the repression of ROR alpha activity [258]. Furthermore, melatonin decreases the activity of Sirtuin 1 (SIRT1), which interacts with Clock to regulate Bmal1 $[259,260]$. SIRT1 directly inhibits the TGF- $\beta 1$ pathway and induces anti-fibrotic effects [261] (Figure 5).

\subsection{Circadian Rhythms and the WNT/B-Catenin Pathway}

The RORs regulation factors act upstream of the WNT/ $\beta$-catenin pathway, which possesses various putative Bmal1 clock-binding sites within its promoter. Through these interactions, circadian genes control cell cycle progression via the WNT pathway [38]. Bmal1 knockdown inhibits the expression and activity of the WNT signaling pathway [262]. Expression levels of WNT-related genes in wild-type mice are higher than those in Bmal1 knockdown mice $[238,263]$. Bmal1, through the canonical WNT/ $\beta$-catenin activation, regulates cell proliferation and cell cycle progression [264]. Bmal1 enhances $\beta$-catenin transcription, reduces $\beta$-catenin degradation, and represses GSK-3 $\beta$ expression [222]. $\beta$-catenin-induced Per2 degradation involves circadian dysregulation in the intestinal mucosa of ApcMin-/+ mice [265].

In physiological conditions, the core circadian genes work in accurate feedback loops and keep the molecular clockworks in the hypothalamic suprachiasmatic nucleus. They can control peripheral clocks or cellular oscillators outside the hypothalamic suprachiasmatic nucleus [216,217]. Per1 and Per2 maintain cell circadian rhythms and regulate cell-related gene expression, such as c-Myc, to sustain the physiological cell cycle $[266,267]$ (Figure 5). 


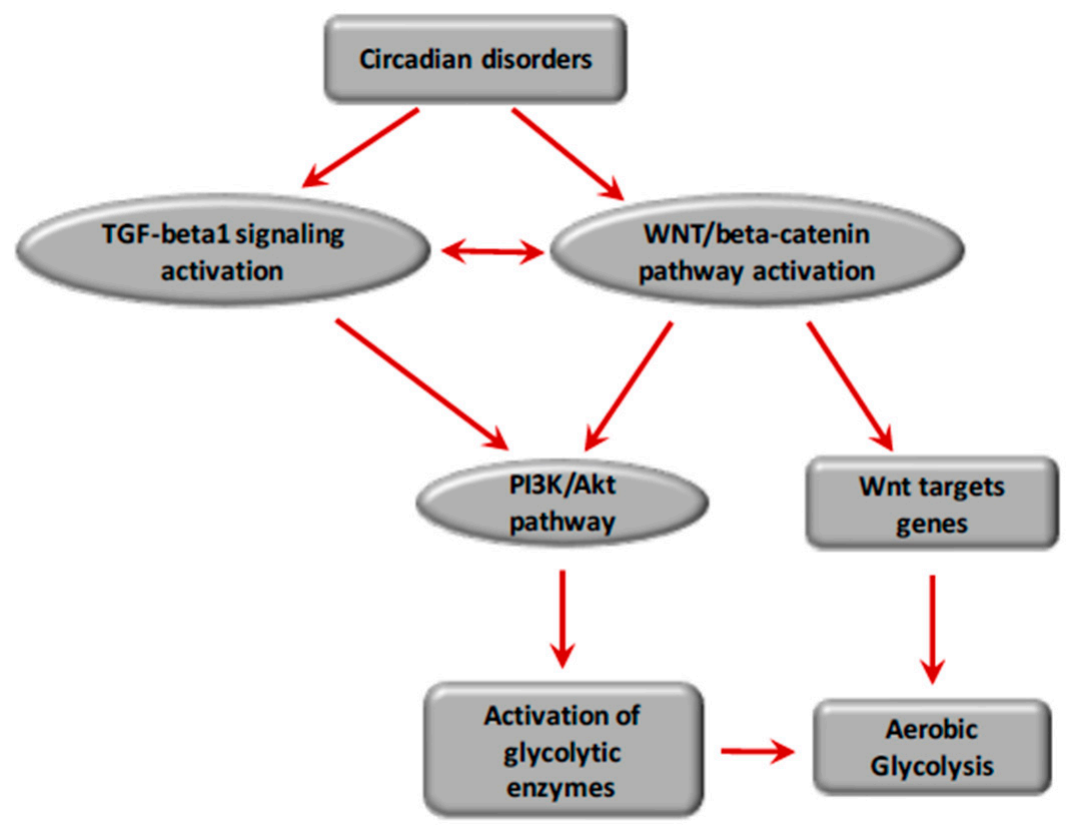

Figure 5. Interactions between circadian disorders and the TGF- $\beta 1$ signaling and WNT/ $\beta$-catenin pathway in the energetic metabolism of fibrosis. Circadiam rhytms disorders are observed in fibrosis. Dysregulation of Bmal1 induces activation of WNT pathway. PI3K/Akt pathway is activated by $\beta$-catenin accumulation and nuclear translocation. The activation of $\beta$-catenin induces transcription of WNT target genes (PDK, MCT-1, c-Myc, cyclin D, PKM2). PDK inhibits the $\mathrm{PDH}$ complex in mitochondria, thus pyruvate can't be fully converted into acetyl-CoA and enter the TCA cycle. C-Myc and cyclin D activates LDH-A which converts cytosolic pyruvate into lactate. This effect is called aerobic glycolisys. Activation of $\mathrm{WNT} / \beta$-catenin pathway induces aerobic glycolisys in fibrosis. Bmal1 stimulation activates TGF- $\beta 1$ by activating Smad3 and inhibiting GSK-3 $\beta$, and then activates fibroblast differentiation into myofibroblasts. PDK, pyruvate dehydrogenase kinase; APC, Adenomatous Polyposis coli; GSK-3 $\beta$, glycogen synthase kinase $3 \beta$; TCF/LEF, T-cell factor/lymphoid enhancer factor; MCT-1, Monocarboxylate Transporter 1; LDH-A, Lactat Dehydrogenase A; PI3K, Phosphatidylinositol-4,5-biphosphatase 3-kinase, PKM2, Pyruvate Kinase M2; PDH, pyruvate dehydrogenase; TCA cycle, Tricarboxylic acid cycle.

\section{Conclusions}

Fibrosis is characterized by fibroblast proliferation and fibroblast differentiation into myofibroblasts, which generate a relaxation-free contraction mechanism associated with excessive collagen synthesis in the extracellular matrix, which promotes an irreversible tissue retraction evolving towards fibrosis. Fibrosis can occur in all tissues and tumors, including the brain.

From a thermodynamic point of view, the mechanisms leading to fibrosis are like many irreversible processes that can occur through changing the entropy production rate. The thermodynamic behavior of metabolic enzymes in fibrosis is modified by the activation of both transforming growth factor TGF- $\beta$ signaling and the canonical WNT/ $\beta$-catenin pathway, which leads to lower conversion of pyruvate into acetyl-coenzyme $\mathrm{A}$ in mitochondria and its entry into the tricarboxylic acid cycle. A major part of cytosolic pyruvate is converted into lactate as the primary alternative of oxidative phosphorylation, despite the availability of oxygen. This phenomenon, called aerobic glycolysis or the Warburg effect, generates energy and is actively involved in reprogramming cellular energy metabolism to enable the process of fibroblast differentiation into myofibroblasts.

Glycolysis is induced in a hypoxia-independent manner by (1) the WNT/ $\beta$-catenin pathway activation via direct activation of WNT target genes, PDK1 and MCT-1 and via the stabilization of the hypoxia-inducible factor 1 alpha (HIF- $1 \alpha)$, and (2) the TGF- $\beta 1$ pathway activation via the 
HIF- $1 \alpha$ stabilization. TGF- $\beta 1$ and WNT $/ \beta$-catenin pathways activate each other in a positive feedback loop through (1) the Smad signaling pathway via Smad2/3, Smad2/3/NOX4/ROS, Smad2/3-4 complex/YAP/TAZ dependent of the Hippo signaling, and (2) the non-Smad signaling pathways such as PI3K/Akt signaling.

HIF- $1 \alpha$ stabilization is sustained in a hypoxia-independent manner through molecular pathways: (1) WNT/ $\beta$-catenin target genes, c-Myc and cyclin D1; (2) WNT/ $\beta$-catenin-induced PI3K/Akt; (3) TGF- $\beta 1$-induced PI3K/Akt; (4) WNT/ $\beta$-catenin-induced TAZ independent of the Hippo signaling; PKM2/ $\beta$-catenin complex-induced c-Myc; and (5) the positive interplay between the molecular pathways TGF- $\beta 1$ and WNT/ $\beta$-catenin. Aberrant HIF signaling with HIF- $1 \alpha$ stabilization induces energy metabolism reprogramming in the context of fibrosis by increasing glycolysis energy metabolism and decreasing the entry of glucose-derived carbons into the TCA cycle, thereby reducing mitochondrial oxidative phosphorylation energy metabolism. HIF- $1 \alpha$ is a central regulator of the glycolysis energy metabolism involved in organ fibrosis, indicating a similarity between inflammation and cancer.

The molecular mechanisms of the fibrotic process, including the TGF- $\beta 1$ and $W N T / \beta$-catenin pathways, can be considered dissipative structures that exchange energy or matter with their environment. They are open systems working far from the thermodynamic equilibrium and operate under a non-linear regime evolving towards non-stationary states. Indeed, circadian rhythms, which are also far-from-equilibrium open thermodynamic systems, directly drive the fibrotic process by regulating the molecular pathways TGF- $\beta 1$ and $W N T / \beta$-catenin involved in the reprogramming of cellular energy metabolism, enabling the differentiation of fibroblasts into myofibroblasts and leading to the fibrotic process.

Conflicts of Interest: The authors declare no conflicts of interest.

\section{References}

1. Richter, K.; Kietzmann, T. Reactive oxygen species and fibrosis: Further evidence of a significant liaison. Cell Tissue Res. 2016, 365, 591-605. [CrossRef] [PubMed]

2. Dvorak, H.F. Tumors: Wounds that do not heal. Similarities between tumor stroma generation and wound healing. N. Engl. J. Med. 1986, 315, 1650-1659. [CrossRef] [PubMed]

3. Dvorak, H.F.; Form, D.M.; Manseau, E.J.; Smith, B.D. Pathogenesis of desmoplasia. I. Immunofluorescence identification and localization of some structural proteins of line 1 and line 10 guinea pig tumors and of healing wounds. J. Natl. Cancer Inst. 1984, 73, 1195-1205. [PubMed]

4. Kalluri, R.; Zeisberg, M. Fibroblasts in cancer. Nat. Rev. Cancer 2006, 6, 392-401. [CrossRef] [PubMed]

5. Rockey, D.C.; Bell, P.D.; Hill, J.A. Fibrosis-A common pathway to organ injury and failure. N. Engl. J. Med. 2015, 373, 96. [CrossRef] [PubMed]

6. Hecker, L.; Jagirdar, R.; Jin, T.; Thannickal, V.J. Reversible differentiation of myofibroblasts by MyoD. Exp. Cell Res. 2011, 317, 1914-1921. [CrossRef] [PubMed]

7. Bucala, R.; Spiegel, L.A.; Chesney, J.; Hogan, M.; Cerami, A. Circulating fibrocytes define a new leukocyte subpopulation that mediates tissue repair. Mol. Med. 1994, 1, 71-81. [PubMed]

8. Lin, S.-L.; Kisseleva, T.; Brenner, D.A.; Duffield, J.S. Pericytes and perivascular fibroblasts are the primary source of collagen-producing cells in obstructive fibrosis of the kidney. Am. J. Pathol. 2008, 173, 1617-1627. [CrossRef] [PubMed]

9. Rønnov-Jessen, L.; Petersen, O.W.; Koteliansky, V.E.; Bissell, M.J. The origin of the myofibroblasts in breast cancer. Recapitulation of tumor environment in culture unravels diversity and implicates converted fibroblasts and recruited smooth muscle cells. J. Clin. Investig. 1995, 95, 859-873. [CrossRef] [PubMed]

10. Kondepudi, D.; Prigogine, I. Modern Thermodynamics from Heat Engines to Dissipative Structures; Wiley \& Sons: New York, NY, USA, 1999.

11. Prigogine, I.; Nicolis, G.; Babloyantz, A. Nonequilibrium problems in biological phenomena. Ann. N. Y. Acad. Sci. 1974, 231, 99-105. [CrossRef] [PubMed]

12. Prigogine, I. Life and physics. New perspectives. Cell Biophys. 1986, 9, 217-224. [CrossRef] [PubMed] 
13. Sandler, S. Chemical and Engineering Thermodynamics, 4th ed.; Wiely: New York, NY, USA, 2006.

14. Lecarpentier, Y.; Schussler, O.; Claes, V.; Vallée, A. The myofibroblast: TGF $\beta-1$, A Conductor which plays a key role in fibrosis by regulating the balance between PPAR $\gamma$ and the canonical Wnt pathway. Nucl. Recept. Res. 2017, 4, 23. [CrossRef] [PubMed]

15. Piersma, B.; Bank, R.A.; Boersema, M. Signaling in Fibrosis: TGF- $\beta$, Wnt, and YAP/TAZ Converge. Front. Med. 2015, 2. [CrossRef] [PubMed]

16. Kottmann, R.M.; Kulkarni, A.A.; Smolnycki, K.A.; Lyda, E.; Dahanayake, T.; Salibi, R.; Honnons, S.; Jones, C.; Isern, N.G.; Hu, J.Z.; et al. Lactic acid is elevated in idiopathic pulmonary fibrosis and induces myofibroblast differentiation via $\mathrm{pH}-$ dependent activation of transforming growth factor- $\beta$. Am. J. Respir. Crit. Care Med. 2012, 186, 740-751. [CrossRef] [PubMed]

17. Meng, X.-M.; Nikolic-Paterson, D.J.; Lan, H.Y. TGF- $\beta$ : The master regulator of fibrosis. Nat. Rev. Nephrol. 2016, 12, 325-338. [CrossRef] [PubMed]

18. Kovács, M.; Wang, F.; Hu, A.; Zhang, Y.; Sellers, J.R. Functional divergence of human cytoplasmic myosin II: Kinetic characterization of the non-muscle IIA isoform. J. Biol. Chem. 2003, 278, 38132-38140. [CrossRef] [PubMed]

19. Lecarpentier, Y.; Claes, V.; Lecarpentier, E.; Guerin, C.; Hébert, J.-L.; Arsalane, A.; Moumen, A.; Krokidis, X.; Michel, F.; Timbely, O. Ultraslow myosin molecular motors of placental contractile stem villi in humans. PLoS ONE 2014, 9, e108814. [CrossRef] [PubMed]

20. Pate, K.T.; Stringari, C.; Sprowl-Tanio, S.; Wang, K.; TeSlaa, T.; Hoverter, N.P.; McQuade, M.M.; Garner, C.; Digman, M.A.; Teitell, M.A.; et al. Wnt signaling directs a metabolic program of glycolysis and angiogenesis in colon cancer. EMBO J. 2014, 33, 1454-1473. [CrossRef] [PubMed]

21. Warburg, O. On the origin of cancer cells. Science 1956, 123, 309-314. [CrossRef] [PubMed]

22. Goldbeter, A.; Pourquié, O. Modeling the segmentation clock as a network of coupled oscillations in the Notch, Wnt and FGF signaling pathways. J. Theor. Biol. 2008, 252, 574-585. [CrossRef] [PubMed]

23. Gabbiani, G.; Chaponnier, C.; Hüttner, I. Cytoplasmic filaments and gap junctions in epithelial cells and myofibroblasts during wound healing. J. Cell Biol. 1978, 76, 561-568. [CrossRef] [PubMed]

24. Serini, G.; Bochaton-Piallat, M.L.; Ropraz, P.; Geinoz, A.; Borsi, L.; Zardi, L.; Gabbiani, G. The fibronectin domain ED-A is crucial for myofibroblastic phenotype induction by transforming growth factor $\beta 1$. J. Cell Biol. 1998, 142, 873-881. [CrossRef] [PubMed]

25. Wei, J.; Bhattacharyya, S.; Jain, M.; Varga, J. Regulation of matrix remodeling by peroxisome proliferator-activated receptor- $\gamma$ : A novel link between metabolism and fibrogenesis. Open Rheumatol. J. 2012, 6, 103-115. [CrossRef] [PubMed]

26. Goffin, J.M.; Pittet, P.; Csucs, G.; Lussi, J.W.; Meister, J.-J.; Hinz, B. Focal adhesion size controls tension-dependent recruitment of alpha-smooth muscle actin to stress fibers. J. Cell Biol. 2006, 172, 259-268. [CrossRef] [PubMed]

27. Tomasek, J.J.; Gabbiani, G.; Hinz, B.; Chaponnier, C.; Brown, R.A. Myofibroblasts and mechano-regulation of connective tissue remodelling. Nat. Rev. Mol. Cell Biol. 2002, 3, 349-363. [CrossRef] [PubMed]

28. Desmoulière, A.; Geinoz, A.; Gabbiani, F.; Gabbiani, G. Transforming growth factor- $\beta 1$ induces $\alpha$-smooth muscle actin expression in granulation tissue myofibroblasts and in quiescent and growing cultured fibroblasts. J. Cell Biol. 1993, 122, 103-111. [CrossRef] [PubMed]

29. Hinz, B.; Celetta, G.; Tomasek, J.J.; Gabbiani, G.; Chaponnier, C. $\alpha$-smooth muscle actin expression upregulates fibroblast contractile activity. Mol. Biol. Cell 2001, 12, 2730-2741. [CrossRef] [PubMed]

30. Dugina, V.; Fontao, L.; Chaponnier, C.; Vasiliev, J.; Gabbiani, G. Focal adhesion features during myofibroblastic differentiation are controlled by intracellular and extracellular factors. J. Cell Sci. 2001, 114, 3285-3296. [PubMed]

31. Van De Water, L.; Varney, S.; Tomasek, J.J. Mechanoregulation of the myofibroblast in wound contraction, scarring, and fibrosis: Opportunities for new therapeutic intervention. Adv. Wound Care 2013, 2, 122-141. [CrossRef] [PubMed]

32. Conti, M.A.; Adelstein, R.S. Nonmuscle myosin II moves in new directions. J. Cell Sci. 2008, 121, 11-18. [CrossRef] [PubMed]

33. Lecarpentier, Y.; Claes, V.; Hébert, J.-L.; Krokidis, X.; Blanc, F.-X.; Michel, F.; Timbely, O. Statistical Mechanics of the human placenta: A stationary state of a near-equilibrium system in a linear regime. PLoS ONE 2015, 10, e0142471. [CrossRef] [PubMed] 
34. Desmoulière, A.; Redard, M.; Darby, I.; Gabbiani, G. Apoptosis mediates the decrease in cellularity during the transition between granulation tissue and scar. Am. J. Pathol. 1995, 146, 56-66. [PubMed]

35. Krantz, E.; Parker, J. Contractile properties of the smooth muscle in the human placenta. Clin. Obstet. Gynecol. 1963, 6, 26-38. [CrossRef]

36. Prigogine, I.; Nicolis, G. Biological order, structure and instabilities. Q. Rev. Biophys. 1971, 4, $107-148$. [CrossRef] [PubMed]

37. Dong, C.; Gongora, R.; Sosulski, M.L.; Luo, F.; Sanchez, C.G. Regulation of transforming growth factor-beta1 (TGF- $\beta 1$ )-induced pro-fibrotic activities by circadian clock gene BMAL1. Respir. Res. 2016, 17, 4. [CrossRef] [PubMed]

38. Soták, M.; Sumová, A.; Pácha, J. Cross-talk between the circadian clock and the cell cycle in cancer. Ann. Med. 2014, 46, 221-232. [CrossRef] [PubMed]

39. Akram, K.M.; Samad, S.; Spiteri, M.; Forsyth, N.R. Mesenchymal stem cell therapy and lung diseases. Adv. Biochem. Eng. Biotechnol. 2013, 130, 105-129. [CrossRef] [PubMed]

40. Aravinthan, A.; Scarpini, C.; Tachtatzis, P.; Verma, S.; Penrhyn-Lowe, S.; Harvey, R.; Davies, S.E.; Allison, M.; Coleman, N.; Alexander, G. Hepatocyte senescence predicts progression in non-alcohol-related fatty liver disease. J. Hepatol. 2013, 58, 549-556. [CrossRef] [PubMed]

41. Rudolph, K.L.; Chang, S.; Millard, M.; Schreiber-Agus, N.; DePinho, R.A. Inhibition of experimental liver cirrhosis in mice by telomerase gene delivery. Science 2000, 287, 1253-1258. [CrossRef] [PubMed]

42. Abraham, D.J.; Shiwen, X.; Black, C.M.; Sa, S.; Xu, Y.; Leask, A. Tumor necrosis factor alpha suppresses the induction of connective tissue growth factor by transforming growth factor-beta in normal and scleroderma fibroblasts. J. Biol. Chem. 2000, 275, 15220-15225. [CrossRef] [PubMed]

43. Ding, N.-H.; Li, J.J.; Sun, L.-Q. Molecular mechanisms and treatment of radiation-induced lung fibrosis. Curr. Drug Targets 2013, 14, 1347-1356. [CrossRef] [PubMed]

44. Hogaboam, C.M.; Blease, K.; Mehrad, B.; Steinhauser, M.L.; Standiford, T.J.; Kunkel, S.L.; Lukacs, N.W. Chronic airway hyperreactivity, goblet cell hyperplasia, and peribronchial fibrosis during allergic airway disease induced by Aspergillus fumigatus. Am. J. Pathol. 2000, 156, 723-732. [CrossRef]

45. Mack, M.; Yanagita, M. Origin of myofibroblasts and cellular events triggering fibrosis. Kidney Int. 2015, 87, 297-307. [CrossRef] [PubMed]

46. Romanelli, R.G.; Caligiuri, A.; Carloni, V.; DeFranco, R.; Montalto, P.; Ceni, E.; Casini, A.; Gentilini, P.; Pinzani, M. Effect of pentoxifylline on the degradation of procollagen type I produced by human hepatic stellate cells in response to transforming growth factor-beta 1. Br. J. Pharmacol. 1997, 122, 1047-1054. [CrossRef] [PubMed]

47. Blobe, G.C.; Schiemann, W.P.; Lodish, H.F. Role of transforming growth factor beta in human disease. N. Engl. J. Med. 2000, 342, 1350-1358. [CrossRef] [PubMed]

48. Zhang, Y.E. Non-Smad pathways in TGF-beta signaling. Cell Res. 2009, 19, 128-139. [CrossRef] [PubMed]

49. Ma, Y.; Zou, H.; Zhu, X.-X.; Pang, J.; Xu, Q.; Jin, Q.-Y.; Ding, Y.-H.; Zhou, B.; Huang, D.-S. Transforming growth factor $\beta$ : A potential biomarker and therapeutic target of ventricular remodeling. Oncotarget 2017, 8 , 53780-53790. [CrossRef] [PubMed]

50. Shyu, K.-G.; Wang, B.-W.; Chen, W.-J.; Kuan, P.; Hung, C.-R. Mechanism of the inhibitory effect of atorvastatin on endoglin expression induced by transforming growth factor-beta1 in cultured cardiac fibroblasts. Eur. J. Heart Fail. 2010, 12, 219-226. [CrossRef] [PubMed]

51. Voloshenyuk, T.G.; Landesman, E.S.; Khoutorova, E.; Hart, A.D.; Gardner, J.D. Induction of cardiac fibroblast lysyl oxidase by TGF- $\beta 1$ requires PI3K/Akt, Smad3, and MAPK signaling. Cytokine 2011, 55, 90-97. [CrossRef] [PubMed]

52. Aragno, M.; Mastrocola, R.; Alloatti, G.; Vercellinatto, I.; Bardini, P.; Geuna, S.; Catalano, M.G.; Danni, O.; Boccuzzi, G. Oxidative stress triggers cardiac fibrosis in the heart of diabetic rats. Endocrinology 2008, 149, 380-388. [CrossRef] [PubMed]

53. Djamali, A.; Vidyasagar, A.; Adulla, M.; Hullett, D.; Reese, S. Nox-2 is a modulator of fibrogenesis in kidney allografts. Am. J. Transplant. 2009, 9, 74-82. [CrossRef] [PubMed]

54. Ha, H.; Lee, H.B. Reactive oxygen species and matrix remodeling in diabetic kidney. J. Am. Soc. Nephrol. 2003, 14, S246-S249. [CrossRef] [PubMed]

55. Murdoch, C.E.; Zhang, M.; Cave, A.C.; Shah, A.M. NADPH oxidase-dependent redox signalling in cardiac hypertrophy, remodelling and failure. Cardiovasc. Res. 2006, 71, 208-215. [CrossRef] [PubMed] 
56. Sirker, A.; Zhang, M.; Murdoch, C.; Shah, A.M. Involvement of NADPH oxidases in cardiac remodelling and heart failure. Am. J. Nephrol. 2007, 27, 649-660. [CrossRef] [PubMed]

57. Babalola, O.; Mamalis, A.; Lev-Tov, H.; Jagdeo, J. NADPH oxidase enzymes in skin fibrosis: Molecular targets and therapeutic agents. Arch. Dermatol. Res. 2014, 306, 313-330. [CrossRef] [PubMed]

58. Barnes, J.L.; Gorin, Y. Myofibroblast differentiation during fibrosis: Role of NAD(P)H oxidases. Kidney Int. 2011, 79, 944-956. [CrossRef] [PubMed]

59. Paik, Y.-H.; Kim, J.; Aoyama, T.; De Minicis, S.; Bataller, R.; Brenner, D.A. Role of NADPH oxidases in liver fibrosis. Antioxid. Redox Signal. 2014, 20, 2854-2872. [CrossRef] [PubMed]

60. Samoylenko, A.; Hossain, J.A.; Mennerich, D.; Kellokumpu, S.; Hiltunen, J.K.; Kietzmann, T. Nutritional countermeasures targeting reactive oxygen species in cancer: From mechanisms to biomarkers and clinical evidence. Antioxid. Redox Signal. 2013, 19, 2157-2196. [CrossRef] [PubMed]

61. Brown, D.I.; Griendling, K.K. Nox proteins in signal transduction. Free Radic. Biol. Med. 2009, 47, $1239-1253$. [CrossRef] [PubMed]

62. O'Neill, S.; Brault, J.; Stasia, M.-J.; Knaus, U.G. Genetic disorders coupled to ROS deficiency. Redox Biol. 2015, 6, 135-156. [CrossRef] [PubMed]

63. Hecker, L.; Vittal, R.; Jones, T.; Jagirdar, R.; Luckhardt, T.R.; Horowitz, J.C.; Pennathur, S.; Martinez, F.J.; Thannickal, V.J. NADPH oxidase-4 mediates myofibroblast activation and fibrogenic responses to lung injury. Nat. Med. 2009, 15, 1077-1081. [CrossRef] [PubMed]

64. Cucoranu, I.; Clempus, R.; Dikalova, A.; Phelan, P.J.; Ariyan, S.; Dikalov, S.; Sorescu, D. NAD(P)H oxidase 4 mediates transforming growth factor- $\beta 1$-induced differentiation of cardiac fibroblasts into myofibroblasts. Circ. Res. 2005, 97, 900-907. [CrossRef] [PubMed]

65. Sedeek, M.; Nasrallah, R.; Touyz, R.M.; Hébert, R.L. NADPH oxidases, reactive oxygen species, and the kidney: Friend and foe. J. Am. Soc. Nephrol. 2013, 24, 1512-1518. [CrossRef] [PubMed]

66. Masamune, A.; Watanabe, T.; Kikuta, K.; Satoh, K.; Shimosegawa, T. NADPH oxidase plays a crucial role in the activation of pancreatic stellate cells. Am. J. Physiol. Gastrointest. Liver Physiol. 2008, 294, G99-G108. [CrossRef] [PubMed]

67. Cui, W.; Matsuno, K.; Iwata, K.; Ibi, M.; Matsumoto, M.; Zhang, J.; Zhu, K.; Katsuyama, M.; Torok, N.J.; Yabe-Nishimura, C. NOX1/nicotinamide adenine dinucleotide phosphate, reduced form (NADPH) oxidase promotes proliferation of stellate cells and aggravates liver fibrosis induced by bile duct ligation. Hepatology 2011, 54, 949-958. [CrossRef] [PubMed]

68. De Minicis, S.; Brenner, D.A. NOX in liver fibrosis. Arch. Biochem. Biophys. 2007, 462, 266-272. [CrossRef] [PubMed]

69. Paik, Y.-H.; Iwaisako, K.; Seki, E.; Inokuchi, S.; Schnabl, B.; Osterreicher, C.H.; Kisseleva, T.; Brenner, D.A. The nicotinamide adenine dinucleotide phosphate oxidase (NOX) homologues NOX1 and NOX2/gp91 phox mediate hepatic fibrosis in mice. Hepatology 2011, 53, 1730-1741. [CrossRef] [PubMed]

70. Radwan, M.I.; Pasha, H.F.; Mohamed, R.H.; Hussien, H.I.M.; El-Khshab, M.N. Influence of transforming growth factor- $\beta 1$ and tumor necrosis factor- $\alpha$ genes polymorphisms on the development of cirrhosis and hepatocellular carcinoma in chronic hepatitis C patients. Cytokine 2012, 60, 271-276. [CrossRef] [PubMed]

71. Boudreau, H.E.; Casterline, B.W.; Rada, B.; Korzeniowska, A.; Leto, T.L. Nox4 involvement in TGF- $\beta$ and Smad3-driven induction of the epithelial-to-mesenchymal transition and migration of breast epithelial cells. Free Radic. Biol. Med. 2012, 53, 1489-1499. [CrossRef] [PubMed]

72. Carmona-Cuenca, I.; Roncero, C.; Sancho, P.; Caja, L.; Fausto, N.; Fernández, M.; Fabregat, I. Upregulation of the NADPH oxidase NOX4 by TGF- $\beta$ in hepatocytes is required for its pro-apoptotic activity. J. Hepatol. 2008, 49, 965-976. [CrossRef] [PubMed]

73. Sturrock, A.; Cahill, B.; Norman, K.; Huecksteadt, T.P.; Hill, K.; Sanders, K.; Karwande, S.V.; Stringham, J.C.; Bull, D.A.; Gleich, M.; et al. Transforming growth factor-beta1 induces Nox4 NAD(P)H oxidase and reactive oxygen species-dependent proliferation in human pulmonary artery smooth muscle cells. Am. J. Physiol. Lung Cell. Mol. Physiol. 2006, 290, L661-L673. [CrossRef] [PubMed]

74. Samarakoon, R.; Overstreet, J.M.; Higgins, P.J. TGF- $\beta$ signaling in tissue fibrosis: Redox controls, target genes and therapeutic opportunities. Cell. Signal. 2013, 25, 264-268. [CrossRef] [PubMed] 
75. Buday, A.; Orsy, P.; Godó, M.; Mózes, M.; Kökény, G.; Lacza, Z.; Koller, A.; Ungvári, Z.; Gross, M.-L.; Benyó, Z.; et al. Elevated systemic TGF-beta impairs aortic vasomotor function through activation of NADPH oxidase-driven superoxide production and leads to hypertension, myocardial remodeling, and increased plaque formation in apoE ${ }^{-/-}$mice. Am. J. Physiol. Heart Circ. Physiol. 2010, 299, H386-H395. [CrossRef] [PubMed]

76. Sancho, P.; Mainez, J.; Crosas-Molist, E.; Roncero, C.; Fernández-Rodriguez, C.M.; Pinedo, F.; Huber, H.; Eferl, R.; Mikulits, W.; Fabregat, I. NADPH oxidase NOX4 mediates stellate cell activation and hepatocyte cell death during liver fibrosis development. PLoS ONE 2012, 7, e45285. [CrossRef] [PubMed]

77. Bondi, C.D.; Manickam, N.; Lee, D.Y.; Block, K.; Gorin, Y.; Abboud, H.E.; Barnes, J.L. NAD(P)H oxidase mediates TGF-beta1-induced activation of kidney myofibroblasts. J. Am. Soc. Nephrol. 2010, 21, 93-102. [CrossRef] [PubMed]

78. Kutz, S.M.; Higgins, C.E.; Samarakoon, R.; Higgins, S.P.; Allen, R.R.; Qi, L.; Higgins, P.J. TGF-beta 1-induced PAI-1 expression is E box/USF-dependent and requires EGFR signaling. Exp. Cell Res. 2006, 312, 1093-1105. [CrossRef] [PubMed]

79. Rhyu, D.Y.; Park, J.; Sharma, B.R.; Ha, H. Role of reactive oxygen species in transforming growth factor-beta1-induced extracellular matrix accumulation in renal tubular epithelial cells. Transplant. Proc. 2012, 44, 625-628. [CrossRef] [PubMed]

80. Samarakoon, R.; Chitnis, S.S.; Higgins, S.P.; Higgins, C.E.; Krepinsky, J.C.; Higgins, P.J. Redox-induced Src kinase and caveolin-1 signaling in TGF- $\beta 1$-initiated SMAD2/3 activation and PAI-1 expression. PLoS ONE 2011, 6, e22896. [CrossRef] [PubMed]

81. Czekay, R.-P.; Wilkins-Port, C.E.; Higgins, S.P.; Freytag, J.; Overstreet, J.M.; Klein, R.M.; Higgins, C.E.; Samarakoon, R.; Higgins, P.J. PAI-1: An integrator of cell signaling and migration. Int. J. Cell Biol. 2011, 2011, 562481. [CrossRef] [PubMed]

82. Eddy, A.A. Serine proteases, inhibitors and receptors in renal fibrosis. Thromb. Haemost. 2009, 101, 656-664. [CrossRef] [PubMed]

83. Oda, T.; Jung, Y.O.; Kim, H.S.; Cai, X.; López-Guisa, J.M.; Ikeda, Y.; Eddy, A.A. PAI-1 deficiency attenuates the fibrogenic response to ureteral obstruction. Kidney Int. 2001, 60, 587-596. [CrossRef] [PubMed]

84. Lakos, G.; Takagawa, S.; Chen, S.-J.; Ferreira, A.M.; Han, G.; Masuda, K.; Wang, X.-J.; DiPietro, L.A.; Varga, J. Targeted disruption of TGF-beta/Smad3 signaling modulates skin fibrosis in a mouse model of scleroderma. Am. J. Pathol. 2004, 165, 203-217. [CrossRef]

85. Samarakoon, R.; Higgins, P.J. Integration of non-SMAD and SMAD signaling in TGF-beta1-induced plasminogen activator inhibitor type-1 gene expression in vascular smooth muscle cells. Thromb. Haemost. 2008, 100, 976-983. [PubMed]

86. Van Geest, R.J.; Klaassen, I.; Vogels, I.M.C.; van Noorden, C.J.F.; Schlingemann, R.O. Differential TGF- $\beta$ signaling in retinal vascular cells: A role in diabetic retinopathy? Investig. Ophthalmol. Vis. Sci. 2010, 51, 1857-1865. [CrossRef] [PubMed]

87. Samarakoon, R.; Higgins, S.P.; Higgins, C.E.; Higgins, P.J. TGF-beta1-induced plasminogen activator inhibitor-1 expression in vascular smooth muscle cells requires pp60 ${ }^{\text {c-src }} / \mathrm{EGFR}^{\mathrm{Y} 845}$ and Rho/ROCK signaling. J. Mol. Cell. Cardiol. 2008, 44, 527-538. [CrossRef] [PubMed]

88. Cordenonsi, M.; Dupont, S.; Maretto, S.; Insinga, A.; Imbriano, C.; Piccolo, S. Links between tumor suppressors: P53 is required for TGF-beta gene responses by cooperating with Smads. Cell 2003, 113, 301-314. [CrossRef]

89. Meek, D.W.; Anderson, C.W. Posttranslational modification of p53: Cooperative integrators of function. Cold Spring Harb. Perspect. Biol. 2009, 1, a000950. [CrossRef] [PubMed]

90. Dendooven, A.; Ishola, D.A.; Nguyen, T.Q.; Van der Giezen, D.M.; Kok, R.J.; Goldschmeding, R.; Joles, J.A. Oxidative stress in obstructive nephropathy. Int. J. Exp. Pathol. 2011, 92, 202-210. [CrossRef] [PubMed]

91. Samarakoon, R.; Overstreet, J.M.; Higgins, S.P.; Higgins, P.J. TGF- $\beta 1 \rightarrow$ SMAD/p53/USF2 $\rightarrow$ PAI-1 transcriptional axis in ureteral obstruction-induced renal fibrosis. Cell Tissue Res. 2012, 347, 117-128. [CrossRef] [PubMed]

92. Dennler, S.; Itoh, S.; Vivien, D.; ten Dijke, P.; Huet, S.; Gauthier, J.M. Direct binding of Smad3 and Smad4 to critical TGF beta-inducible elements in the promoter of human plasminogen activator inhibitor-type 1 gene. EMBO J. 1998, 17, 3091-3100. [CrossRef] [PubMed] 
93. Milliat, F.; Sabourin, J.-C.; Tarlet, G.; Holler, V.; Deutsch, E.; Buard, V.; Tamarat, R.; Atfi, A.; Benderitter, M.; François, A. Essential role of plasminogen activator inhibitor type-1 in radiation enteropathy. Am. J. Pathol. 2008, 172, 691-701. [CrossRef] [PubMed]

94. Ben-Neriah, Y.; Karin, M. Inflammation meets cancer, with NF-kB as the matchmaker. Nat. Immunol. 2011, 12, 715-723. [CrossRef] [PubMed]

95. Gloire, G.; Legrand-Poels, S.; Piette, J. NF-кB activation by reactive oxygen species: Fifteen years later. Biochem. Pharmacol. 2006, 72, 1493-1505. [CrossRef] [PubMed]

96. Karin, M.; Greten, F.R. NF-kB: Linking inflammation and immunity to cancer development and progression. Nat. Rev. Immunol. 2005, 5, 749-759. [CrossRef] [PubMed]

97. Andersson-Sjöland, A.; Karlsson, J.C.; Rydell-Törmänen, K. ROS-induced endothelial stress contributes to pulmonary fibrosis through pericytes and Wnt signaling. Lab. Investig. J. Tech. Methods Pathol. 2016, 96, 206-217. [CrossRef] [PubMed]

98. Aumiller, V.; Balsara, N.; Wilhelm, J.; Günther, A.; Königshoff, M. Wnt/ $\beta$-catenin signaling induces IL-1 $\beta$ expression by alveolar epithelial cells in pulmonary fibrosis. Am. J. Respir. Cell Mol. Biol. 2013, 49, 96-104. [CrossRef] [PubMed]

99. Baarsma, H.A.; Spanjer, A.I.R.; Haitsma, G.; Engelbertink, L.H.J.M.; Meurs, H.; Jonker, M.R.; Timens, W.; Postma, D.S.; Kerstjens, H.A.M.; Gosens, R. Activation of Wnt/ $\beta$-catenin signaling in pulmonary fibroblasts by TGF- $\beta_{1}$ is increased in chronic obstructive pulmonary disease. PLoS ONE 2011, 6, e25450. [CrossRef] [PubMed]

100. Dees, C.; Distler, J.H.W. Canonical Wnt signalling as a key regulator of fibrogenesis-Implications for targeted therapies? Exp. Dermatol. 2013, 22, 710-713. [CrossRef] [PubMed]

101. Königshoff, M.; Kneidinger, N.; Eickelberg, O. TGF- $\beta$ signaling in COPD: Deciphering genetic and cellular susceptibilities for future therapeutic regimen. Swiss Med. Wkly. 2009, 139, 554-563. [PubMed]

102. Königshoff, M.; Eickelberg, O. Wnt signaling in lung disease: A failure or a regeneration signal? Am. J. Respir. Cell Mol. Biol. 2010, 42, 21-31. [CrossRef] [PubMed]

103. Wei, J.; Fang, F.; Lam, A.P.; Sargent, J.L.; Hamburg, E.; Hinchcliff, M.E.; Gottardi, C.J.; Atit, R.; Whitfield, M.L.; Varga, J. Wnt/ $\beta$-catenin signaling is hyperactivated in systemic sclerosis and induces Smad-dependent fibrotic responses in mesenchymal cells. Arthritis Rheumatol. 2012, 64, 2734-2745. [CrossRef] [PubMed]

104. Van Amerongen, R.; Nusse, R. Towards an integrated view of Wnt signaling in development. Dev. Camb. Engl. 2009, 136, 3205-3214. [CrossRef] [PubMed]

105. Al-Harthi, L. Wnt/ $\beta$-catenin and its Diverse Physiological Cell Signaling Pathways in Neurodegenerative and Neuropsychiatric Disorders. J. Neuroimmune Pharmacol. 2012, 7, 725-730. [CrossRef] [PubMed]

106. Lecarpentier, Y.; Claes, V.; Duthoit, G.; Hébert, J.-L. Circadian rhythms, Wnt/beta-catenin pathway and $\operatorname{PPAR} \alpha / \gamma$ profiles in diseases with primary or secondary cardiac dysfunction. Front. Physiol. 2014, 5, 429. [CrossRef] [PubMed]

107. Logan, C.Y.; Nusse, R. The Wnt signaling pathway in development and disease. Annu. Rev. Cell Dev. Biol. 2004, 20, 781-810. [CrossRef] [PubMed]

108. Angers, S.; Moon, R.T. Proximal events in Wnt signal transduction. Nat. Rev. Mol. Cell Biol. 2009. [CrossRef] [PubMed]

109. Clevers, H.; Nusse, R. Wnt/ $\beta$-catenin signaling and disease. Cell 2012, 149, 1192-1205. [CrossRef] [PubMed]

110. Aberle, H.; Bauer, A.; Stappert, J.; Kispert, A.; Kemler, R. $\beta$-catenin is a target for the ubiquitin-proteasome pathway. EMBO J. 1997, 16, 3797-3804. [CrossRef] [PubMed]

111. Karin, M. NF-кB as a critical link between inflammation and cancer. Cold Spring Harb. Perspect. Biol. 2009, 1, a000141. [CrossRef] [PubMed]

112. Pasparakis, M. Regulation of tissue homeostasis by NF-kappaB signalling: Implications for inflammatory diseases. Nat. Rev. Immunol. 2009, 9, 778-788. [CrossRef] [PubMed]

113. Tak, P.P.; Firestein, G.S. NF-kappaB: A key role in inflammatory diseases. J. Clin. Investig. 2001, 107, 7-11. [CrossRef] [PubMed]

114. Oguma, K.; Oshima, H.; Aoki, M.; Uchio, R.; Naka, K.; Nakamura, S.; Hirao, A.; Saya, H.; Taketo, M.M.; Oshima, M. Activated macrophages promote Wnt signalling through tumour necrosis factor- $\alpha$ in gastric tumour cells. EMBO J. 2008, 27, 1671-1681. [CrossRef] [PubMed] 
115. Zhang, Y.; Tomann, P.; Andl, T.; Gallant, N.M.; Huelsken, J.; Jerchow, B.; Birchmeier, W.; Paus, R.; Piccolo, S.; Mikkola, M.L.; et al. Reciprocal requirements for EDA/EDAR/NF- $\mathrm{B}$ and Wnt/ $\beta$-catenin signaling pathways in hair follicle induction. Dev. Cell 2009, 17, 49-61. [CrossRef] [PubMed]

116. Nejak-Bowen, K.; Kikuchi, A.; Monga, S.P.S. Beta-catenin-NF-кB interactions in murine hepatocytes: A complex to die for. Hepatology 2013, 57, 763-774. [CrossRef] [PubMed]

117. Ma, B.; Hottiger, M.O. Crosstalk between Wnt/ $\beta$-Catenin and NF-kB Signaling Pathway during Inflammation. Front. Immunol. 2016, 7, 378. [CrossRef] [PubMed]

118. Yun, K.; Choi, Y.D.; Nam, J.H.; Park, Z.; Im, S.-H. NF-kappaB regulates Lef1 gene expression in chondrocytes. Biochem. Biophys. Res. Commun. 2007, 357, 589-595. [CrossRef] [PubMed]

119. Spiegelman, V.S.; Slaga, T.J.; Pagano, M.; Minamoto, T.; Ronai, Z.; Fuchs, S.Y. Wnt/beta-catenin signaling induces the expression and activity of betaTrCP ubiquitin ligase receptor. Mol. Cell 2000, 5, 877-882. [CrossRef]

120. Noubissi, F.K.; Elcheva, I.; Bhatia, N.; Shakoori, A.; Ougolkov, A.; Liu, J.; Minamoto, T.; Ross, J.; Fuchs, S.Y.; Spiegelman, V.S. CRD-BP mediates stabilization of betaTrCP1 and c-Myc mRNA in response to beta-catenin signalling. Nature 2006, 441, 898-901. [CrossRef] [PubMed]

121. Kuphal, S.; Poser, I.; Jobin, C.; Hellerbrand, C.; Bosserhoff, A.K. Loss of E-cadherin leads to upregulation of NFkappaB activity in malignant melanoma. Oncogene 2004, 23, 8509-8519. [CrossRef] [PubMed]

122. Anson, M.; Crain-Denoyelle, A.-M.; Baud, V.; Chereau, F.; Gougelet, A.; Terris, B.; Yamagoe, S.; Colnot, S.; Viguier, M.; Perret, C.; et al. Oncogenic $\beta$-catenin triggers an inflammatory response that determines the aggressiveness of hepatocellular carcinoma in mice. J. Clin. Investig. 2012, 122, 586-599. [CrossRef] [PubMed]

123. Wang, X.; Adhikari, N.; Li, Q.; Guan, Z.; Hall, J.L. The role of $\beta$-transducin repeat-containing protein $(\beta-\operatorname{TrCP})$ in the regulation of NF-[kappa]B in vascular smooth muscle cells. Arterioscler. Thromb. Vasc. Biol. 2004, 24, 85-90. [CrossRef] [PubMed]

124. Yang, H.; Zhao, L.-F.; Zhao, Z.-F.; Wang, Y.; Zhao, J.-J.; Zhang, L. Heme oxygenase-1 prevents liver fibrosis in rats by regulating the expression of PPAR $\gamma$ and NF-кB. World J. Gastroenterol. 2012, 18, 1680-1688. [CrossRef] [PubMed]

125. Colston, J.T.; de la Rosa, S.D.; Koehler, M.; Gonzales, K.; Mestril, R.; Freeman, G.L.; Bailey, S.R.; Chandrasekar, B. Wnt-induced secreted protein-1 is a prohypertrophic and profibrotic growth factor. Am. J. Physiol. Heart Circ. Physiol. 2007, 293, H1839-H1846. [CrossRef] [PubMed]

126. Königshoff, M.; Kramer, M.; Balsara, N.; Wilhelm, J.; Amarie, O.V.; Jahn, A.; Rose, F.; Fink, L.; Seeger, W.; Schaefer, L.; et al. WNT1-inducible signaling protein-1 mediates pulmonary fibrosis in mice and is upregulated in humans with idiopathic pulmonary fibrosis. J. Clin. Investig. 2009, 119, 772-787. [CrossRef] [PubMed]

127. Desnoyers, L.; Arnott, D.; Pennica, D. WISP-1 binds to decorin and biglycan. J. Biol. Chem. 2001, 276, 47599-47607. [CrossRef] [PubMed]

128. Li, X.; Chen, Y.; Ye, W.; Tao, X.; Zhu, J.; Wu, S.; Lou, L. Blockade of CCN4 attenuates CCl4-induced liver fibrosis. Arch. Med. Sci. 2015, 11, 647-653. [CrossRef] [PubMed]

129. Brazil, D.P.; Yang, Z.-Z.; Hemmings, B.A. Advances in protein kinase B signalling: AKTion on multiple fronts. Trends Biochem. Sci. 2004, 29, 233-242. [CrossRef] [PubMed]

130. Ciuffreda, L.; Di Sanza, C.; Incani, U.C.; Milella, M. The mTOR pathway: A new target in cancer therapy. Curr. Cancer Drug Targets 2010, 10, 484-495. [CrossRef] [PubMed]

131. Heras-Sandoval, D.; Pérez-Rojas, J.M.; Hernández-Damián, J.; Pedraza-Chaverri, J. The role of $\mathrm{PI} 3 \mathrm{~K} / \mathrm{AKT} / \mathrm{mTOR}$ pathway in the modulation of autophagy and the clearance of protein aggregates in neurodegeneration. Cell. Signal. 2014, 26, 2694-2701. [CrossRef] [PubMed]

132. Yu, J.S.L.; Cui, W. Proliferation, survival and metabolism: The role of PI3K/AKT/mTOR signalling in pluripotency and cell fate determination. Dev. Camb. Engl. 2016, 143, 3050-3060. [CrossRef] [PubMed]

133. Chen, J.; Alberts, I.; Li, X. Dysregulation of the IGF-I/PI3K/AKT/mTOR signaling pathway in autism spectrum disorders. Int. J. Dev. Neurosci. 2014, 35, 35-41. [CrossRef] [PubMed]

134. Huang, J.; Nguyen-McCarty, M.; Hexner, E.O.; Danet-Desnoyers, G.; Klein, P.S. Maintenance of hematopoietic stem cells through regulation of Wnt and mTOR pathways. Nat. Med. 2012, 18, 1778-1785. [CrossRef] [PubMed] 
135. Zhou, B.; Buckley, S.T.; Patel, V.; Liu, Y.; Luo, J.; Krishnaveni, M.S.; Ivan, M.; DeMaio, L.; Kim, K.-J.; Ehrhardt, C.; et al. Troglitazone attenuates TGF- $\beta 1$-induced EMT in alveolar epithelial cells via a PPAR $\gamma$-independent mechanism. PLoS ONE 2012, 7, e38827. [CrossRef] [PubMed]

136. Ambacher, K.K.; Pitzul, K.B.; Karajgikar, M.; Hamilton, A.; Ferguson, S.S.; Cregan, S.P. The JNK- and AKT/GSK3 $\beta$-Signaling Pathways Converge to Regulate Puma Induction and Neuronal Apoptosis Induced by Trophic Factor Deprivation. PLoS ONE 2012, 7, e46885. [CrossRef] [PubMed]

137. Hur, E.-M.; Zhou, F.-Q. GSK3 signalling in neural development. Nat. Rev. Neurosci. 2010, 11, $539-551$. [CrossRef] [PubMed]

138. Wu, D.; Pan, W. GSK3: A multifaceted kinase in Wnt signaling. Trends Biochem. Sci. 2010, 35, 161-168. [CrossRef] [PubMed]

139. Ross, S.E.; Erickson, R.L.; Hemati, N.; MacDougald, O.A. Glycogen synthase kinase 3 is an insulin-regulated C/EBPalpha kinase. Mol. Cell. Biol. 1999, 19, 8433-8441. [CrossRef] [PubMed]

140. Tang, Q.-Q.; Grønborg, M.; Huang, H.; Kim, J.-W.; Otto, T.C.; Pandey, A.; Lane, M.D. Sequential phosphorylation of CCAAT enhancer-binding protein beta by MAPK and glycogen synthase kinase 3beta is required for adipogenesis. Proc. Natl. Acad. Sci. USA 2005, 102, 9766-9771. [CrossRef] [PubMed]

141. Paik, Y.-H.; Kim, J.K.; Lee, J.I.; Kang, S.H.; Kim, D.Y.; An, S.H.; Lee, S.J.; Lee, D.K.; Han, K.-H.; Chon, C.Y.; et al. Celecoxib induces hepatic stellate cell apoptosis through inhibition of Akt activation and suppresses hepatic fibrosis in rats. Gut 2009, 58, 1517-1527. [CrossRef] [PubMed]

142. Son, G.; Hines, I.N.; Lindquist, J.; Schrum, L.W.; Rippe, R.A. Inhibition of phosphatidylinositol 3-kinase signaling in hepatic stellate cells blocks the progression of hepatic fibrosis. Hepatology 2009, 50, 1512-1523. [CrossRef] [PubMed]

143. Kulkarni, A.A.; Thatcher, T.H.; Olsen, K.C.; Maggirwar, S.B.; Phipps, R.P.; Sime, P.J. PPAR- $\gamma$ ligands repress TGF $\beta$-induced myofibroblast differentiation by targeting the PI3K/Akt pathway: Implications for therapy of fibrosis. PLoS ONE 2011, 6, e15909. [CrossRef] [PubMed]

144. Qin, J.; Xie, Y.-Y.; Huang, L.; Yuan, Q.-J.; Mei, W.-J.; Yuan, X.-N.; Hu, G.-Y.; Cheng, G.-J.; Tao, L.-J.; Peng, Z.-Z. Fluorofenidone inhibits nicotinamide adeninedinucleotide phosphate oxidase via PI3K/Akt pathway in the pathogenesis of renal interstitial fibrosis. Nephrology 2013, 18, 690-699. [CrossRef] [PubMed]

145. Park, K.S.; Lee, R.D.; Kang, S.-K.; Han, S.Y.; Park, K.L.; Yang, K.H.; Song, Y.S.; Park, H.J.; Lee, Y.M.; Yun, Y.P.; et al. Neuronal differentiation of embryonic midbrain cells by upregulation of peroxisome proliferator-activated receptor-gamma via the JNK-dependent pathway. Exp. Cell Res. 2004, 297, 424-433. [CrossRef] [PubMed]

146. Yue, X.; Lan, F.; Yang, W.; Yang, Y.; Han, L.; Zhang, A.; Liu, J.; Zeng, H.; Jiang, T.; Pu, P.; et al. Interruption of $\beta$-catenin suppresses the EGFR pathway by blocking multiple oncogenic targets in human glioma cells. Brain Res. 2010, 1366, 27-37. [CrossRef] [PubMed]

147. Buss, H.; Dörrie, A.; Schmitz, M.L.; Frank, R.; Livingstone, M.; Resch, K.; Kracht, M. Phosphorylation of serine 468 by GSK-3beta negatively regulates basal p65 NF-kappaB activity. J. Biol. Chem. 2004, 279, 49571-49574. [CrossRef] [PubMed]

148. Saegusa, M.; Hashimura, M.; Kuwata, T.; Hamano, M.; Okayasu, I. Crosstalk between NF-kappaB/p65 and beta-catenin/TCF4/p300 signalling pathways through alterations in GSK-3beta expression during trans-differentiation of endometrial carcinoma cells. J. Pathol. 2007, 213, 35-45. [CrossRef] [PubMed]

149. Carthy, J.M.; Garmaroudi, F.S.; Luo, Z.; McManus, B.M. Wnt3a induces myofibroblast differentiation by upregulating TGF- $\beta$ signaling through SMAD2 in a $\beta$-catenin-dependent manner. PLoS ONE 2011, 6, e19809. [CrossRef] [PubMed]

150. Lam, A.P.; Herazo-Maya, J.D.; Sennello, J.A.; Flozak, A.S.; Russell, S.; Mutlu, G.M.; Budinger, G.R.S.; DasGupta, R.; Varga, J.; Kaminski, N.; et al. Wnt Coreceptor Lrp5 Is a Driver of Idiopathic Pulmonary Fibrosis. Am. J. Respir. Crit. Care Med. 2014, 190, 185-195. [CrossRef] [PubMed]

151. Alarcón, C.; Zaromytidou, A.-I.; Xi, Q.; Gao, S.; Yu, J.; Fujisawa, S.; Barlas, A.; Miller, A.N.; Manova-Todorova, K.; Macias, M.J.; Sapkota, G.; Pan, D.; Massagué, J. CDK8/9 drive Smad transcriptional action, turnover and YAP interactions in BMP and TGF $\beta$ pathways. Cell 2009, 139, 757-769. [CrossRef] [PubMed]

152. Akhmetshina, A.; Palumbo, K.; Dees, C.; Bergmann, C.; Venalis, P.; Zerr, P.; Horn, A.; Kireva, T.; Beyer, C.; Zwerina, J.; et al. Activation of canonical Wnt signalling is required for TGF- $\beta$-mediated fibrosis. Nat. Commun. 2012, 3, 735. [CrossRef] [PubMed] 
153. Furuhashi, M.; Yagi, K.; Yamamoto, H.; Furukawa, Y.; Shimada, S.; Nakamura, Y.; Kikuchi, A.; Miyazono, K.; Kato, M. Axin Facilitates Smad3 Activation in the Transforming Growth Factor $\beta$ Signaling Pathway. Mol. Cell. Biol. 2001, 21, 5132-5141. [CrossRef] [PubMed]

154. Liu, W.; Rui, H.; Wang, J.; Lin, S.; He, Y.; Chen, M.; Li, Q.; Ye, Z.; Zhang, S.; Chan, S.C.; et al. Axin is a scaffold protein in TGF- $\beta$ signaling that promotes degradation of Smad7 by Arkadia. EMBO J. 2006, 25, 1646-1658. [CrossRef] [PubMed]

155. Hayashi, H.; Abdollah, S.; Qiu, Y.; Cai, J.; Xu, Y.Y.; Grinnell, B.W.; Richardson, M.A.; Topper, J.N.; Gimbrone, M.A.; Wrana, J.L.; et al. The MAD-related protein Smad7 associates with the TGFbeta receptor and functions as an antagonist of TGFbeta signaling. Cell 1997, 89, 1165-1173. [CrossRef]

156. Ferrigno, O.; Lallemand, F.; Verrecchia, F.; L'Hoste, S.; Camonis, J.; Atfi, A.; Mauviel, A. Yes-associated protein (YAP65) interacts with Smad7 and potentiates its inhibitory activity against TGF-beta/Smad signaling. Oncogene 2002, 21, 4879-4884. [CrossRef] [PubMed]

157. Han, G.; Li, A.G.; Liang, Y.-Y.; Owens, P.; He, W.; Lu, S.; Yoshimatsu, Y.; Wang, D.; Ten Dijke, P.; Lin, X.; Wang, X.-J. Smad7-induced beta-catenin degradation alters epidermal appendage development. Dev. Cell 2006, 11, 301-312. [CrossRef] [PubMed]

158. Liu, F.; Lagares, D.; Choi, K.M.; Stopfer, L.; Marinković, A.; Vrbanac, V.; Probst, C.K.; Hiemer, S.E.; Sisson, T.H.; Horowitz, J.C.; et al. Mechanosignaling through YAP and TAZ drives fibroblast activation and fibrosis. Am. J. Physiol. Lung Cell. Mol. Physiol. 2015, 308, L344-L357. [CrossRef] [PubMed]

159. Mannaerts, I.; Leite, S.B.; Verhulst, S.; Claerhout, S.; Eysackers, N.; Thoen, L.F.R.; Hoorens, A.; Reynaert, H.; Halder, G.; van Grunsven, L.A. The Hippo pathway effector YAP controls mouse hepatic stellate cell activation. J. Hepatol. 2015, 63, 679-688. [CrossRef] [PubMed]

160. Varelas, X.; Samavarchi-Tehrani, P.; Narimatsu, M.; Weiss, A.; Cockburn, K.; Larsen, B.G.; Rossant, J.; Wrana, J.L. The Crumbs complex couples cell density sensing to Hippo-dependent control of the TGF- $\beta$-SMAD pathway. Dev. Cell 2010, 19, 831-844. [CrossRef] [PubMed]

161. Imajo, M.; Miyatake, K.; Iimura, A.; Miyamoto, A.; Nishida, E. A molecular mechanism that links Hippo signalling to the inhibition of Wnt/ $\beta$-catenin signalling. EMBO J. 2012, 31, 1109-1122. [CrossRef] [PubMed]

162. Varelas, X.; Sakuma, R.; Samavarchi-Tehrani, P.; Peerani, R.; Rao, B.M.; Dembowy, J.; Yaffe, M.B.; Zandstra, P.W.; Wrana, J.L. TAZ controls Smad nucleocytoplasmic shuttling and regulates human embryonic stem-cell self-renewal. Nat. Cell Biol. 2008, 10, 837-848. [CrossRef] [PubMed]

163. Azzolin, L.; Zanconato, F.; Bresolin, S.; Forcato, M.; Basso, G.; Bicciato, S.; Cordenonsi, M.; Piccolo, S. Role of TAZ as mediator of Wnt signaling. Cell 2012, 151, 1443-1456. [CrossRef] [PubMed]

164. Bhattacharyya, S.; Wei, J.; Tourtellotte, W.G.; Hinchcliff, M.; Gottardi, C.G.; Varga, J. Fibrosis in systemic sclerosis: Common and unique pathobiology. Fibrogenesis Tissue Repair 2012, 5, S18. [CrossRef] [PubMed]

165. Varga, J.; Pasche, B. Transforming growth factor beta as a therapeutic target in systemic sclerosis. Nat. Rev. Rheumatol. 2009, 5, 200-206. [CrossRef] [PubMed]

166. Georgescu, M.-M. PTEN Tumor Suppressor Network in PI3K-Akt Pathway Control. Genes Cancer 2010, 1 , 1170-1177. [CrossRef] [PubMed]

167. White, E.S.; Atrasz, R.G.; Hu, B.; Phan, S.H.; Stambolic, V.; Mak, T.W.; Hogaboam, C.M.; Flaherty, K.R.; Martinez, F.J.; Kontos, C.D.; et al. Negative regulation of myofibroblast differentiation by PTEN (Phosphatase and Tensin Homolog Deleted on chromosome 10). Am. J. Respir. Crit. Care Med. 2006, 173, 112-121. [CrossRef] [PubMed]

168. Vallée, A.; Lecarpentier, Y.; Guillevin, R.; Vallée, J.-N. Aerobic Glycolysis Hypothesis through Wnt/Beta-Catenin Pathway in Exudative Age-Related Macular Degeneration. J. Mol. Neurosci. 2017, 62, 368-379. [CrossRef] [PubMed]

169. Chen, Z.; Liu, M.; Li, L.; Chen, L. Involvement of the Warburg effect in non-tumor diseases processes. J. Cell. Physiol. 2017. [CrossRef] [PubMed]

170. Berg, J.; Tymoczko, J. Oxidative phosphorylation. In Biochemistry; W.H. Freeman and Company: New York, NY, USA, 2002; Chapter 18; pp. 491-526.

171. Pfeiffer, T.; Schuster, S.; Bonhoeffer, S. Cooperation and competition in the evolution of ATP-producing pathways. Science 2001, 292, 504-507. [CrossRef] [PubMed]

172. Lunt, S.Y.; Vander Heiden, M.G. Aerobic glycolysis: Meeting the metabolic requirements of cell proliferation. Annu. Rev. Cell Dev. Biol. 2011, 27, 441-464. [CrossRef] [PubMed] 
173. Vander Heiden, M.G.; Cantley, L.C.; Thompson, C.B. Understanding the Warburg effect: The metabolic requirements of cell proliferation. Science 2009, 324, 1029-1033. [CrossRef] [PubMed]

174. Lecarpentier, Y.; Claes, V.; Vallée, A.; Hébert, J.-L. Thermodynamics in cancers: Opposing interactions between PPAR gamma and the canonical Wnt/beta-catenin pathway. Clin. Transl. Med. 2017, 6, 14. [CrossRef] [PubMed]

175. Thompson, C.B. Wnt meets Warburg: Another piece in the puzzle? EMBO J. 2014, 33, 1420-1422. [CrossRef] [PubMed]

176. Vallée, A.; Lecarpentier, Y.; Guillevin, R.; Vallée, J.-N. Thermodynamics in Gliomas: Interactions between the Canonical Wnt/Beta-Catenin Pathway and PPAR Gamma. Front. Physiol. 2017, 8, 352. [CrossRef] [PubMed]

177. Semenza, G.L. Regulation of metabolism by hypoxia-inducible factor 1. Cold Spring Harb. Symp. Quant. Biol. 2011, 76, 347-353. [CrossRef] [PubMed]

178. Keith, B.; Johnson, R.S.; Simon, M.C. HIF1 $\alpha$ and HIF2 $\alpha$ : Sibling rivalry in hypoxic tumour growth and progression. Nat. Rev. Cancer 2011, 12, 9-22. [CrossRef] [PubMed]

179. Venneti, S.; Thompson, C.B. Metabolic Reprogramming in Brain Tumors. Annu. Rev. Pathol. 2017, 12, 515-545. [CrossRef] [PubMed]

180. Xie, N.; Tan, Z.; Banerjee, S.; Cui, H.; Ge, J.; Liu, R.-M.; Bernard, K.; Thannickal, V.J.; Liu, G. Glycolytic Reprogramming in Myofibroblast Differentiation and Lung Fibrosis. Am. J. Respir. Crit. Care Med. 2015, 192, 1462-1474. [CrossRef] [PubMed]

181. Luo, W.; Hu, H.; Chang, R.; Zhong, J.; Knabel, M.; O’Meally, R.; Cole, R.N.; Pandey, A.; Semenza, G.L. Pyruvate kinase M2 is a PHD3-stimulated coactivator for hypoxia-inducible factor 1. Cell 2011, 145, 732-744. [CrossRef] [PubMed]

182. Semenza, G.L. HIF-1: Upstream and downstream of cancer metabolism. Curr. Opin. Genet. Dev. 2010, 20, 51-56. [CrossRef] [PubMed]

183. Sun, Q.; Chen, X.; Ma, J.; Peng, H.; Wang, F.; Zha, X.; Wang, Y.; Jing, Y.; Yang, H.; Chen, R.; et al. Mammalian target of rapamycin up-regulation of pyruvate kinase isoenzyme type M2 is critical for aerobic glycolysis and tumor growth. Proc. Natl. Acad. Sci. USA 2011, 108, 4129-4134. [CrossRef] [PubMed]

184. Kim, J.; Tchernyshyov, I.; Semenza, G.L.; Dang, C.V. HIF-1-mediated expression of pyruvate dehydrogenase kinase: A metabolic switch required for cellular adaptation to hypoxia. Cell Metab. 2006, 3, 177-185. [CrossRef] [PubMed]

185. Semenza, G.L.; Roth, P.H.; Fang, H.M.; Wang, G.L. Transcriptional regulation of genes encoding glycolytic enzymes by hypoxia-inducible factor 1. J. Biol. Chem. 1994, 269, 23757-23763. [PubMed]

186. Reuter, S.; Gupta, S.C.; Chaturvedi, M.M.; Aggarwal, B.B. Oxidative stress, inflammation, and cancer: How are they linked? Free Radic. Biol. Med. 2010, 49, 1603-1616. [CrossRef] [PubMed]

187. McEwen, B.S.; Reagan, L.P. Glucose transporter expression in the central nervous system: Relationship to synaptic function. Eur. J. Pharmacol. 2004, 490, 13-24. [CrossRef] [PubMed]

188. Christofk, H.R.; Vander Heiden, M.G.; Harris, M.H.; Ramanathan, A.; Gerszten, R.E.; Wei, R.; Fleming, M.D.; Schreiber, S.L.; Cantley, L.C. The M2 splice isoform of pyruvate kinase is important for cancer metabolism and tumour growth. Nature 2008, 452, 230-233. [CrossRef] [PubMed]

189. Harris, R.A.; Tindale, L.; Cumming, R.C. Age-dependent metabolic dysregulation in cancer and Alzheimer's disease. Biogerontology 2014, 15, 559-577. [CrossRef] [PubMed]

190. Lv, L.; Li, D.; Zhao, D.; Lin, R.; Chu, Y.; Zhang, H.; Zha, Z.; Liu, Y.; Li, Z.; Xu, Y.; et al. Acetylation targets the $\mathrm{M} 2$ isoform of pyruvate kinase for degradation through chaperone-mediated autophagy and promotes tumor growth. Mol. Cell 2011, 42, 719-730. [CrossRef] [PubMed]

191. Yang, W.; Xia, Y.; Hawke, D.; Li, X.; Liang, J.; Xing, D.; Aldape, K.; Hunter, T.; Alfred Yung, W.K.; Lu, Z. PKM2 phosphorylates histone $\mathrm{H} 3$ and promotes gene transcription and tumorigenesis. Cell 2012, 150, 685-696. [CrossRef] [PubMed]

192. Ding, H.; Jiang, L.; Xu, J.; Bai, F.; Zhou, Y.; Yuan, Q.; Luo, J.; Zen, K.; Yang, J. Inhibiting aerobic glycolysis suppresses renal interstitial fibroblasts activation and renal fibrosis. Am. J. Physiol. Ren. Physiol. 2017. [CrossRef] [PubMed]

193. Goldbeter, A. Patterns of spatiotemporal organization in an allosteric enzyme model. Proc. Natl. Acad. Sci. USA 1973, 70, 3255-3259. [CrossRef] [PubMed]

194. Nicolis, G.; Prigogine, I. Fluctuations in nonequilibrium systems. Proc. Natl. Acad. Sci. USA 1971, 68, 2102-2107. [CrossRef] [PubMed] 
195. Wise, D.R.; DeBerardinis, R.J.; Mancuso, A.; Sayed, N.; Zhang, X.-Y.; Pfeiffer, H.K.; Nissim, I.; Daikhin, E.; Yudkoff, M.; McMahon, S.B.; et al. Myc regulates a transcriptional program that stimulates mitochondrial glutaminolysis and leads to glutamine addiction. Proc. Natl. Acad. Sci. USA 2008, 105, 18782-18787. [CrossRef] [PubMed]

196. Metallo, C.M.; Gameiro, P.A.; Bell, E.L.; Mattaini, K.R.; Yang, J.; Hiller, K.; Jewell, C.M.; Johnson, Z.R.; Irvine, D.J.; Guarente, L.; et al. Reductive glutamine metabolism by IDH1 mediates lipogenesis under hypoxia. Nature 2011, 481, 380-384. [CrossRef] [PubMed]

197. Mullen, A.R.; Wheaton, W.W.; Jin, E.S.; Chen, P.-H.; Sullivan, L.B.; Cheng, T.; Yang, Y.; Linehan, W.M.; Chandel, N.S.; DeBerardinis, R.J. Reductive carboxylation supports growth in tumour cells with defective mitochondria. Nature 2011, 481, 385-388. [CrossRef] [PubMed]

198. Wise, D.R.; Ward, P.S.; Shay, J.E.S.; Cross, J.R.; Gruber, J.J.; Sachdeva, U.M.; Platt, J.M.; DeMatteo, R.G.; Simon, M.C.; Thompson, C.B. Hypoxia promotes isocitrate dehydrogenase-dependent carboxylation of $\alpha$-ketoglutarate to citrate to support cell growth and viability. Proc. Natl. Acad. Sci. USA 2011, 108, 19611-19616. [CrossRef] [PubMed]

199. Kim, J.; Gao, P.; Liu, Y.-C.; Semenza, G.L.; Dang, C.V. Hypoxia-inducible factor 1 and dysregulated c-Myc cooperatively induce vascular endothelial growth factor and metabolic switches hexokinase 2 and pyruvate dehydrogenase kinase 1. Mol. Cell. Biol. 2007, 27, 7381-7393. [CrossRef] [PubMed]

200. Tannahill, G.M.; Curtis, A.M.; Adamik, J.; Palsson-McDermott, E.M.; McGettrick, A.F.; Goel, G.; Frezza, C.; Bernard, N.J.; Kelly, B.; Foley, N.H.; et al. Succinate is an inflammatory signal that induces IL-1 $\beta$ through HIF-1 $\alpha$. Nature 2013, 496, 238-242. [CrossRef] [PubMed]

201. Lu, H.; Forbes, R.A.; Verma, A. Hypoxia-inducible factor 1 activation by aerobic glycolysis implicates the Warburg effect in carcinogenesis. J. Biol. Chem. 2002, 277, 23111-23115. [CrossRef] [PubMed]

202. Yeung, S.J.; Pan, J.; Lee, M.-H. Roles of p53, MYC and HIF-1 in regulating glycolysis—The seventh hallmark of cancer. Cell. Mol. Life Sci. 2008, 65, 3981-3999. [CrossRef] [PubMed]

203. Aluwihare, P.; Munger, J.S. What the lung has taught us about latent TGF-beta activation. Am. J. Respir. Cell Mol. Biol. 2008, 39, 499-502. [CrossRef] [PubMed]

204. Khalil, N. TGF-beta: From latent to active. Microbes Infect. 1999, 1, 1255-1263. [CrossRef]

205. Wipff, P.-J.; Hinz, B. Integrins and the activation of latent transforming growth factor beta1-An intimate relationship. Eur. J. Cell Biol. 2008, 87, 601-615. [CrossRef] [PubMed]

206. Annes, J.P.; Munger, J.S.; Rifkin, D.B. Making sense of latent TGFbeta activation. J. Cell Sci. 2003, 116, $217-224$. [CrossRef] [PubMed]

207. Lawrence, D.A.; Pircher, R.; Jullien, P. Conversion of a high molecular weight latent beta-TGF from chicken embryo fibroblasts into a low molecular weight active beta-TGF under acidic conditions. Biochem. Biophys. Res. Commun. 1985, 133, 1026-1034. [CrossRef]

208. Bartram, U.; Speer, C.P. The role of transforming growth factor beta in lung development and disease. Chest 2004, 125, 754-765. [CrossRef] [PubMed]

209. Kelly, M.; Kolb, M.; Bonniaud, P.; Gauldie, J. Re-evaluation of fibrogenic cytokines in lung fibrosis. Curr. Pharm. Des. 2003, 9, 39-49. [CrossRef] [PubMed]

210. Sime, P.J.; Xing, Z.; Graham, F.L.; Csaky, K.G.; Gauldie, J. Adenovector-mediated gene transfer of active transforming growth factor-beta1 induces prolonged severe fibrosis in rat lung. J. Clin. Investig. 1997, 100, 768-776. [CrossRef] [PubMed]

211. Cao, Y.; Wang, H.; Ouyang, Q.; Tu, Y. The free energy cost of accurate biochemical oscillations. Nat. Phys. 2015, 11, 772-778. [CrossRef] [PubMed]

212. Goldbeter, A. Biochemical Oscillations and Cellular Rhythms: The Molecular Bases of Periodic and Chaotic Behaviour; Cambridge University Press: Cambridge, UK, 1996.

213. Hogenesch, J.B.; Ueda, H.R. Understanding systems-level properties: Timely stories from the study of clocks. Nat. Rev. Genet. 2011, 12, 407-416. [CrossRef] [PubMed]

214. Hogenesch, J.B.; Gu, Y.Z.; Jain, S.; Bradfield, C.A. The basic-helix-loop-helix-PAS orphan MOP3 forms transcriptionally active complexes with circadian and hypoxia factors. Proc. Natl. Acad. Sci. USA 1998, 95, 5474-5479. [CrossRef] [PubMed]

215. Gekakis, N.; Staknis, D.; Nguyen, H.B.; Davis, F.C.; Wilsbacher, L.D.; King, D.P.; Takahashi, J.S.; Weitz, C.J. Role of the CLOCK protein in the mammalian circadian mechanism. Science 1998, 280, 1564-1569. [CrossRef] [PubMed] 
216. Reppert, S.M.; Weaver, D.R. Coordination of circadian timing in mammals. Nature 2002, 418, $935-941$. [CrossRef] [PubMed]

217. Schibler, U.; Sassone-Corsi, P. A web of circadian pacemakers. Cell 2002, 111, 919-922. [CrossRef]

218. Ko, C.H.; Takahashi, J.S. Molecular components of the mammalian circadian clock. Hum. Mol. Genet. 2006, 15, R271-R277. [CrossRef] [PubMed]

219. Goodwin, B.C. Oscillatory behavior in enzymatic control processes. Adv. Enzyme Regul. 1965, 3, 425-438. [CrossRef]

220. Hardin, P.E.; Hall, J.C.; Rosbash, M. Feedback of the Drosophila period gene product on circadian cycling of its messenger RNA levels. Nature 1990, 343, 536-540. [CrossRef] [PubMed]

221. Goldbeter, A. Computational approaches to cellular rhythms. Nature 2002, 420, 238-245. [CrossRef] [PubMed]

222. Sahar, S.; Sassone-Corsi, P. Metabolism and cancer: The circadian clock connection. Nat. Rev. Cancer 2009, 9, 886-896. [CrossRef] [PubMed]

223. Garfinkel, D.; Zisapel, N. Liver cirrhosis and circadian rhythm. Ann. Intern. Med. 1996, 125, 154. [CrossRef] [PubMed]

224. Montagnese, S.; Middleton, B.; Mani, A.R.; Skene, D.J.; Morgan, M.Y. Sleep and circadian abnormalities in patients with cirrhosis: Features of delayed sleep phase syndrome? Metab. Brain Dis. 2009, 24, 427-439. [CrossRef] [PubMed]

225. Piscaglia, F.; Siringo, S.; Hermida, R.C.; Legnani, C.; Valgimigli, M.; Donati, G.; Palareti, G.; Gramantieri, L.; Gaiani, S.; Burroughs, A.K.; et al. Diurnal changes of fibrinolysis in patients with liver cirrhosis and esophageal varices. Hepatology 2000, 31, 349-357. [CrossRef] [PubMed]

226. Chen, P.; Han, Z.; Yang, P.; Zhu, L.; Hua, Z.; Zhang, J. Loss of clock gene mPer2 promotes liver fibrosis induced by carbon tetrachloride. Hepatol. Res. 2010, 40, 1117-1127. [CrossRef] [PubMed]

227. Chen, P.; Kakan, X.; Wang, S.; Dong, W.; Jia, A.; Cai, C.; Zhang, J. Deletion of clock gene Per2 exacerbates cholestatic liver injury and fibrosis in mice. Exp. Toxicol. Pathol. 2013, 65, 427-432. [CrossRef] [PubMed]

228. Wang, C.-Y.; Wen, M.-S.; Wang, H.-W.; Hsieh, I.-C.; Li, Y.; Liu, P.-Y.; Lin, F.-C.; Liao, J.K. Increased vascular senescence and impaired endothelial progenitor cell function mediated by mutation of circadian gene Per2. Circulation 2008, 118, 2166-2173. [CrossRef] [PubMed]

229. Kondratov, R.V.; Kondratova, A.A.; Gorbacheva, V.Y.; Vykhovanets, O.V.; Antoch, M.P. Early aging and age-related pathologies in mice deficient in BMAL1, the core componentof the circadian clock. Genes Dev. 2006, 20, 1868-1873. [CrossRef] [PubMed]

230. Kang, T.-H.; Reardon, J.T.; Kemp, M.; Sancar, A. Circadian oscillation of nucleotide excision repair in mammalian brain. Proc. Natl. Acad. Sci. USA 2009, 106, 2864-2867. [CrossRef] [PubMed]

231. Zuber, A.M.; Centeno, G.; Pradervand, S.; Nikolaeva, S.; Maquelin, L.; Cardinaux, L.; Bonny, O.; Firsov, D. Molecular clock is involved in predictive circadian adjustment of renal function. Proc. Natl. Acad. Sci. USA 2009, 106, 16523-16528. [CrossRef] [PubMed]

232. Palm, F.; Nordquist, L. Renal oxidative stress, oxygenation, and hypertension. Am. J. Physiol. Regul. Integr. Comp. Physiol. 2011, 301, R1229-R1241. [CrossRef] [PubMed]

233. Brenner, B.M.; Cooper, M.E.; de Zeeuw, D.; Keane, W.F.; Mitch, W.E.; Parving, H.H.; Remuzzi, G.; Snapinn, S.M.; Zhang, Z.; Shahinfar, S. RENAAL Study Investigators Effects of losartan on renal and cardiovascular outcomes in patients with type 2 diabetes and nephropathy. N. Engl. J. Med. 2001, 345, 861-869. [CrossRef] [PubMed]

234. Maschio, G.; Alberti, D.; Janin, G.; Locatelli, F.; Mann, J.F.; Motolese, M.; Ponticelli, C.; Ritz, E.; Zucchelli, P. Effect of the angiotensin-converting-enzyme inhibitor benazepril on the progression of chronic renal insufficiency. The Angiotensin-Converting-Enzyme Inhibition in Progressive Renal Insufficiency Study Group. N. Engl. J. Med. 1996, 334, 939-945. [CrossRef] [PubMed]

235. Kojetin, D.; Wang, Y.; Kamenecka, T.M.; Burris, T.P. Identification of SR8278, a synthetic antagonist of the nuclear heme receptor REV-ERB. ACS Chem. Biol. 2011, 6, 131-134. [CrossRef] [PubMed]

236. Sundar, I.K.; Yao, H.; Sellix, M.T.; Rahman, I. Circadian molecular clock in lung pathophysiology. Am. J. Physiol. Lung Cell. Mol. Physiol. 2015, 309, L1056-L1075. [CrossRef] [PubMed]

237. Nam, D.; Guo, B.; Chatterjee, S.; Chen, M.-H.; Nelson, D.; Yechoor, V.K.; Ma, K. The adipocyte clock controls brown adipogenesis through the TGF- $\beta$ and BMP signaling pathways. J. Cell Sci. 2015, 128, 1835-1847. [CrossRef] [PubMed] 
238. Janich, P.; Pascual, G.; Merlos-Suárez, A.; Batlle, E.; Ripperger, J.; Albrecht, U.; Cheng, H.-Y.M.; Obrietan, K.; Di Croce, L.; Benitah, S.A. The circadian molecular clock creates epidermal stem cell heterogeneity. Nature 2011, 480, 209-214. [CrossRef] [PubMed]

239. Besing, R.C.; Paul, J.R.; Hablitz, L.M.; Rogers, C.O.; Johnson, R.L.; Young, M.E.; Gamble, K.L. Circadian rhythmicity of active GSK3 isoforms modulates molecular clock gene rhythms in the suprachiasmatic nucleus. J. Biol. Rhythms 2015, 30, 155-160. [CrossRef] [PubMed]

240. Hua, F.; Zhou, J.; Liu, J.; Zhu, C.; Cui, B.; Lin, H.; Liu, Y.; Jin, W.; Yang, H.; Hu, Z. Glycogen synthase kinase-3beta negatively regulates TGF-beta1 and Angiotensin II-mediated cellular activity through interaction with Smad3. Eur. J. Pharmacol. 2010, 644, 17-23. [CrossRef] [PubMed]

241. Csernus, V.; Mess, B. Biorhythms and pineal gland. Neuro Endocrinol. Lett. 2003, 24, 404-411. [PubMed]

242. Mauriz, J.L.; Collado, P.S.; Veneroso, C.; Reiter, R.J.; González-Gallego, J. A review of the molecular aspects of melatonin's anti-inflammatory actions: Recent insights and new perspectives. J. Pineal Res. 2013, 54, 1-14. [CrossRef] [PubMed]

243. Crowley, S.J.; Eastman, C.I. Melatonin in the afternoons of a gradually advancing sleep schedule enhances the circadian rhythm phase advance. Psychopharmacology 2013, 225, 825-837. [CrossRef] [PubMed]

244. Wang, X.; Sirianni, A.; Pei, Z.; Cormier, K.; Smith, K.; Jiang, J.; Zhou, S.; Wang, H.; Zhao, R.; Yano, H.; et al. The melatonin MT1 receptor axis modulates mutant Huntingtin-mediated toxicity. J. Neurosci. 2011, 31, 14496-14507. [CrossRef] [PubMed]

245. Rosales-Corral, S.A.; Acuña-Castroviejo, D.; Coto-Montes, A.; Boga, J.A.; Manchester, L.C.; Fuentes-Broto, L.; Korkmaz, A.; Ma, S.; Tan, D.-X.; Reiter, R.J. Alzheimer's disease: Pathological mechanisms and the beneficial role of melatonin. J. Pineal Res. 2012, 52, 167-202. [CrossRef] [PubMed]

246. Galano, A.; Tan, D.X.; Reiter, R.J. On the free radical scavenging activities of melatonin's metabolites, AFMK and AMK. J. Pineal Res. 2013, 54, 245-257. [CrossRef] [PubMed]

247. Calvo, J.R.; González-Yanes, C.; Maldonado, M.D. The role of melatonin in the cells of the innate immunity: A review. J. Pineal Res. 2013, 55, 103-120. [CrossRef] [PubMed]

248. Zhang, H.-M.; Zhang, Y. Melatonin: A well-documented antioxidant with conditional pro-oxidant actions. J. Pineal Res. 2014, 57, 131-146. [CrossRef] [PubMed]

249. Giese, K.P. GSK-3: A key player in neurodegeneration and memory. IUBMB Life 2009, 61, 516-521. [CrossRef] [PubMed]

250. Hoppe, J.B.; Frozza, R.L.; Horn, A.P.; Comiran, R.A.; Bernardi, A.; Campos, M.M.; Battastini, A.M.O.; Salbego, C. Amyloid-beta neurotoxicity in organotypic culture is attenuated by melatonin: Involvement of GSK-3beta, tau and neuroinflammation. J. Pineal Res. 2010, 48, 230-238. [CrossRef] [PubMed]

251. Arslan, S.O.; Zerin, M.; Vural, H.; Coskun, A. The effect of melatonin on bleomycin-induced pulmonary fibrosis in rats. J. Pineal Res. 2002, 32, 21-25. [CrossRef] [PubMed]

252. Zhao, H.; Wu, Q.-Q.; Cao, L.-F.; Qing, H.-Y.; Zhang, C.; Chen, Y.-H.; Wang, H.; Liu, R.Y.L.; Liu, R.-R.; $\mathrm{Xu}, \mathrm{D} . \mathrm{X}$. Melatonin inhibits endoplasmic reticulum stress and epithelial-mesenchymal transition during bleomycin-induced pulmonary fibrosis in mice. PLoS ONE 2014, 9, e97266. [CrossRef] [PubMed]

253. Carossino, A.M.; Lombardi, A.; Matucci-Cerinic, M.; Pignone, A.; Cagnoni, M. Effect of melatonin on normal and sclerodermic skin fibroblast proliferation. Clin. Exp. Rheumatol. 1996, 14, 493-498. [PubMed]

254. Lee, Y.-J.; Lee, J.-H.; Moon, J.-H.; Park, S.-Y. Overcoming hypoxic-resistance of tumor cells to TRAIL-induced apoptosis through melatonin. Int. J. Mol. Sci. 2014, 15, 11941-11956. [CrossRef] [PubMed]

255. Simonini, G.; Pignone, A.; Generini, S.; Falcini, F.; Cerinic, M.M.; Gabriele, S.; Alberto, P.; Sergio, G.; Fernanda, F.; Marco, M.C. Emerging potentials for an antioxidant therapy as a new approach to the treatment of systemic sclerosis. Toxicology 2000, 155, 1-15. [PubMed]

256. Todisco, M. Effectiveness of a treatment based on melatonin in five patients with systemic sclerosis. Am. J. Ther. 2006, 13, 84-87. [CrossRef] [PubMed]

257. Zhou, Q.; Gui, S.; Zhou, Q.; Wang, Y. Melatonin inhibits the migration of human lung adenocarcinoma A549 cell lines involving JNK/MAPK pathway. PLoS ONE 2014, 9, e101132. [CrossRef] [PubMed]

258. Hill, S.M.; Frasch, T.; Xiang, S.; Yuan, L.; Duplessis, T.; Mao, L. Molecular mechanisms of melatonin anticancer effects. Integr. Cancer Ther. 2009, 8, 337-346. [CrossRef] [PubMed]

259. Jung-Hynes, B.; Reiter, R.J.; Ahmad, N. Sirtuins, melatonin and circadian rhythms: Building a bridge between aging and cancer. J. Pineal Res. 2010, 48, 9-19. [CrossRef] [PubMed] 
260. Nakahata, Y.; Kaluzova, M.; Grimaldi, B.; Sahar, S.; Hirayama, J.; Chen, D.; Guarente, L.P.; Sassone-Corsi, P. The NAD+-dependent deacetylase SIRT1 modulates CLOCK-mediated chromatin remodeling and circadian control. Cell 2008, 134, 329-340. [CrossRef] [PubMed]

261. Zerr, P.; Palumbo-Zerr, K.; Huang, J.; Tomcik, M.; Sumova, B.; Distler, O.; Schett, G.; Distler, J.H.W. Sirt1 regulates canonical TGF- $\beta$ signalling to control fibroblast activation and tissue fibrosis. Ann. Rheum. Dis. 2016, 75, 226-233. [CrossRef] [PubMed]

262. Guo, B.; Chatterjee, S.; Li, L.; Kim, J.M.; Lee, J.; Yechoor, V.K.; Minze, L.J.; Hsueh, W.; Ma, K. The clock gene, brain and muscle Arnt-like 1, regulates adipogenesis via Wnt signaling pathway. FASEB J. 2012, 26, 3453-3463. [CrossRef] [PubMed]

263. Yasuniwa, Y.; Izumi, H.; Wang, K.-Y.; Shimajiri, S.; Sasaguri, Y.; Kawai, K.; Kasai, H.; Shimada, T.; Miyake, K.; Kashiwagi, E.; et al. Circadian disruption accelerates tumor growth and angio/stromagenesis through a Wnt signaling pathway. PLoS ONE 2010, 5, e15330. [CrossRef] [PubMed]

264. Lin, F.; Chen, Y.; Li, X.; Zhao, Q.; Tan, Z. Over-expression of circadian clock gene Bmal1 affects proliferation and the canonical Wnt pathway in NIH-3T3 cells. Cell Biochem. Funct. 2013, 31, 166-172. [CrossRef] [PubMed]

265. Yang, X.; Wood, P.A.; Ansell, C.M.; Ohmori, M.; Oh, E.-Y.; Xiong, Y.; Berger, F.G.; Peña, M.M.O.; Hrushesky, W.J.M. Beta-catenin induces beta-TrCP-mediated PER2 degradation altering circadian clock gene expression in intestinal mucosa of ApcMin/+ mice. J. Biochem. 2009, 145, 289-297. [CrossRef] [PubMed]

266. Duffield, G.E.; Best, J.D.; Meurers, B.H.; Bittner, A.; Loros, J.J.; Dunlap, J.C. Circadian programs of transcriptional activation, signaling, and protein turnover revealed by microarray analysis of mammalian cells. Curr. Biol. 2002, 12, 551-557. [CrossRef]

267. Sancar, A.; Lindsey-Boltz, L.A.; Unsal-Kaçmaz, K.; Linn, S. Molecular mechanisms of mammalian DNA repair and the DNA damage checkpoints. Annu. Rev. Biochem. 2004, 73, 39-85. [CrossRef] [PubMed]

(C) 2017 by the authors. Licensee MDPI, Basel, Switzerland. This article is an open access article distributed under the terms and conditions of the Creative Commons Attribution (CC BY) license (http:/ / creativecommons.org/licenses/by/4.0/). 